\title{
POSSÍVEL RELAÇÃO ENTRE ACOPLAMENTO E CICLO CELULAR NA NEURODEGENERAÇÃO DA RETINA
}

Dissertação apresentada ao Programa de Pós-Graduação em Fisiologia Humana do Instituto de Ciências Biomédicas da Universidade de São Paulo, para obtenção do Título de Mestre em Ciências.

São Paulo

2012 


\section{POSSÍVEL RELAÇÃO ENTRE ACOPLAMENTO E CICLO CELULAR NA NEURODENERAÇÃO DA RETINA}

Dissertação apresentada ao Programa de PósGraduação em Fisiologia Humana do Instituto de Ciências Biomédicas da Universidade de São Paulo, para obtenção do Título de Mestre em Ciências.

Área de Concentração: Fisiologia Humana

Orientador: Prof. Dr. Alexandre Hiroaki Kihara

Versão original.

São Paulo

2012 
DADOS DE CATALOGAÇĀO NA PUBLICAÇĀO (CIP)

Serviço de Biblioteca e Informaçăo Biomédica do Instituto de Ciências Biomédicas da Universidade de Săo Paulo

reproduçāo nāo autorizada pelo autor

Higa, Guilherme Shigueto Vilar.

Possivel relação entre acoplamento e ciclo celular na

neurodegeneração da retina / Guilherme Shigueto Vilar Higa. -- São

Paulo, 2012.

Orientador: Prof. Dr. Alexandre Hiroaki Kihara.

Dissertação (Mestrado) - Universidade de São Paulo. Instituto de Ciências Biomédicas. Departamento de Fisiologia e Biofisica. Área de concentração: Fisiologia Humana. Linha de pesquisa: Comunicação celular.

Versão do título para o inglês: Possible relation between cell coupling and cell cycle in the retina during neurodegeneration.

1. Retina 2. Conexinas 3. Junções comunicantes 4. Ciclinas 5. Ciclo celular 6. Neurodegeneração I. Kihara, Prof. Dr. Alexandre Hiroaki II. Universidade de São Paulo. Instituto de Ciências Biomédicas. Programa de Pós-Graduação em Fisiologia Humana III. Titulo. 
UNIVERSIDADE DE SÃO PAULO

INSTITUTO DE CIÊNCIAS BIOMÉDICAS

Candidato(a): $\quad$ Guilherme Shigueto Vilar Higa.

Titulo da Dissertação: $\quad$ Possivel relação entre acoplamento e ciclo celular na neurodegeneração da retina.

Orientador(a): $\quad$ Prof. Dr. Alexandre Hiroaki Kihara.

A Comissão Julgadora dos trabalhos de Defesa da Dissertação de Mestrado, em sessāo pública realizada a I...............................,

( ) Aprovado(a) ( ) Reprovado(a)

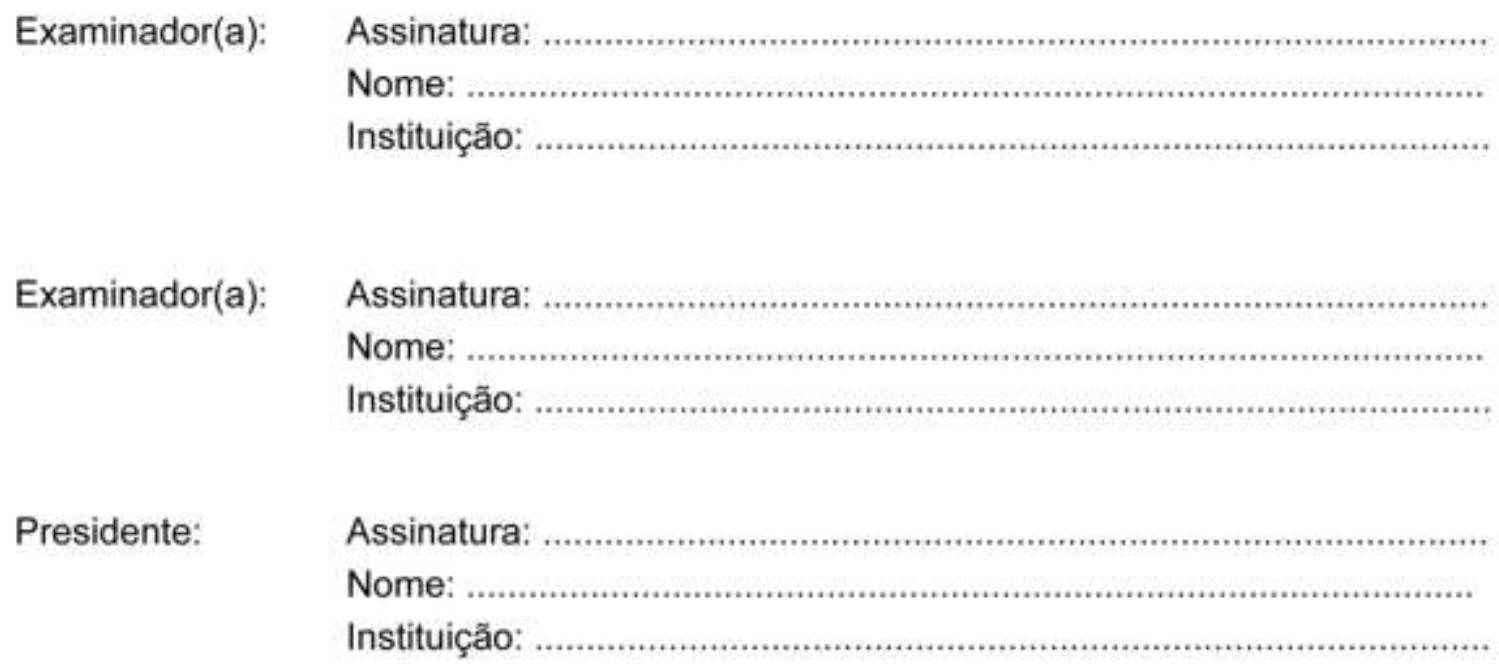




\section{UNIVERSIDADE DE SÃO PAULO INSTITUTO DE CIÊNCIAS BIOMÉDICAS}

Cidade Universitaria "Armando de Salles Oliveira"

Av. Prof, Lineu Prestes. 2415 - CEP, 05508.000 Säo Paulo, SP - Brasil

Telefone : (S5) (011) 3091.7733 - e-muil: -vp ieb usp br

\section{Certificado}

Certificamos que o protocolo tegistrado sob n" $\mathbf{3 7}$ mas ths. 85 do livro $\mathbf{0 2}$ para uso de animais em experimentacios. sob at tesponsabilidade do Prof(a) Drat

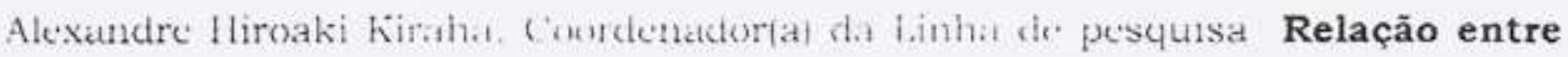
acoplamento e ciclo celular na neurodegeneração du quail purticupou(aram) o(s) Guilherme Shigueto Vilar Higa, Vera Paschon e os pesquisadores Luiz Roberto G. de Britto, est. ile arouto com os Principios Elicos de Experimentacas Animat adotado pela Son iedake Brasilera de (iencia de Inimais de

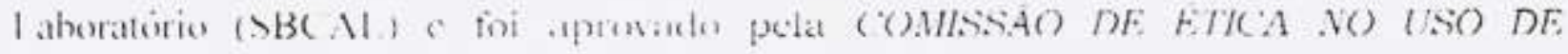
ANIMALS KLELA) um 30.03.2010, wan Validade de .3 anos.

Säo Panto. 0.3 de mato de 2010.

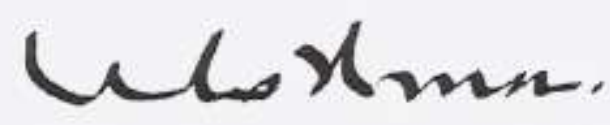

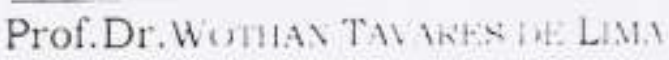

Coordenador

CEEA - ICB L'SP

\section{Prola,Dra.Pliktot Gavi}

Secretaria

CEFA ICB/LSP 
Aos meus pais, Sizuo e Celi, a minha irmã Beatriz e a minha parceira Marcela, pelos momentos alegres, amor, ensinamentos, incentivo, apoio... vocês são indispensáveis na minha vida. 


\section{AGRADECIMENTOS}

Ao meu orientador Prof. Alexandre H. Kihara, por ter me apresentado à pesquisa. Obrigado por permitir participar da missão de "montar" um novo laboratório de pesquisa. Agradeço por estar presente, pelo apoio constante durante as atividades intensas no laboratório, pela calma e paciência para resolução dos pequenos e grandes problemas que enfrentamos no dia a dia, sempre na tentativa de aprimorar a qualidade de nossa pesquisa.

Agradeço a FAPESP, CAPES e CNPQ por financiarem nossos estudos.

Aos professores da graduação de da pós-graduação, pelo rico conhecimento compartilhado que ajudaram a aumentar minha admiração pela ciência.

Aos membros da minha banca de qualificação, Professores Britto, Giselle e Daniel, pelas valiosas sugestões.

Agradeço aos amigos do laboratório do Prof. Britto e da Profa Andreia pelas ricas discussões e pelos grandes momentos de descontração e apoio que sempre tive com eles.

As minhas amigas e companheiras de trabalho, Erika e Vivian pela amizade, apoio em todos os momentos e pelas ricas discussões.

Agradeço a todos meus companheiros de trabalho. Vocês foram essenciais para meu progresso até então. Agradeço ao Otávio pelos inúmeros PCRs e pelas dezenas de experimentos que corremos juntos. A Erica e a Lais pela preciosa ajuda e amizade nos momentos difíceis. A Vera, Vivian, Daniel e Marjorie pela ajuda e colaboração constante no nosso trabalho diário no laboratório. A nossos técnicos, Carol e Michael, por ajudarem a manter nossas soluções do dia a dia. Ao Fausto pelas conversas enriquecedoras.

Agradeço a todos meus amigos da escola e do prédio que sempre fizeram parte da minha vida, pessoas que me apoiaram em todos momentos da minha vida.

Agradeço principalmente aos meus pais e minha irmã pelo amor e afeto, por incentivarem e permitirem seguir a pesquisa e a vida acadêmica. Agradeço pelo apoio e compreensão, pela confiança que sempre tiveram em mim. Agradeço muito ao meu amor, Marcela Baptista por cada momento alegre, pela ajuda e amizade em todos os momentos que tivemos até então. 


\section{RESUMO}

Higa GSV. Possível relação entre acoplamento e ciclo celular. [dissertação (Mestrado em Fisiologia Humana)]. São Paulo: Instituto de Ciências Biomédicas, Universidade de São Paulo; 2012.

A sinalização no sistema nervoso pode ocorrer pelo acoplamento direto entre células, via canais de junção comunicantes (JCs). Estes canais permitem a passagem de moléculas de até $1 \mathrm{kDa}$, e são formados por subunidades proteicas denominadas conexinas (Cxs). A comunicação celular via JCs desempenha um importante papel durante o desenvolvimento e a sinalização visual. Além disso, o acoplamento celular provido pelas JCs tem sido relacionado a processos de sobrevivência/morte celular. Do mesmo modo, ciclinas e cinases dependentes de ciclinas (CDKs), além de seu papel clássico na regulação do ciclo e diferenciação celular, estão envolvidas em processos neurodegenerativos. Estudos recentes têm observado a reentrada no ciclo celular de células neuronais pós-mitóticas em apoptose. Neste contexto, analisamos a expressão gênica e proteica das Cxs e ciclinas em resposta às lesões no sistema visual, especificamente na retina. Estas análises foram realizadas após a indução de trauma mecânico, modelo experimental que permite a visualização do foco, penumbra e áreas adjacentes à lesão. Utilizando técnicas combinadas, como a reação em cadeia da polimerase em tempo real (PCR Real-Time), Western Blot e imuno-histoquímica, avaliamos a expressão espaço-temporal destes genes e as proteínas por eles codificadas, em diferentes tempos pós-lesão. Os resultados da PCR Real-Time revelaram uma ausência de modulação da expressão gênica de Cx36 para os diferentes tempos pós-lesão analisados. A Cx43 mostrou aumento dos transcritos, após três e sete dias pós-lesão. A ciclina D1 e B1 apresentaram modulação significativa após um, três e sete dias pós-lesão. As análises de imuno-histoquímica revelaram uma redistribuição da $C \times 36$ em resposta à lesão em diferentes tempos póslesão. A Cx43, por sua vez, apresentou um aumento aparente de sua expressão no foco e zona de penumbra da lesão, nos período de um, três e sete dias pós-lesão. Em retinas, após um e três dias de lesão, a ciclina D1 encontrou-se presente em células próximas ao foco da lesão. Observamos a presença de ciclina B1 no foco da lesão após um dia de lesão. Por meio de análises de Western Blot não foi possível detectar alterações das diferentes proteínas estudadas nas retinas, em períodos variados de exposição à lesão. Os dados deste estudo sugerem que i) possivelmente, as células afetadas pela lesão se encontram acopladas; ii) expressam proteínas reguladoras do ciclo celular. Levando em consideração o conjunto de resultados, sugerimos que é possível induzir ou prevenir a reentrada do ciclo celular em células pós-mitóticas da retina, controlando o acoplamento mediado pelas proteínas formadoras das JC.

Palavras-chave: Retina. Conexinas. Junções Comunicantes. Ciclinas. Ciclo Celular. Neurodegeneração. 


\begin{abstract}
Higa GSV. Possible relation between cell coupling and cell cycle in the retina during neurodegeneration. [Masters thesis (Human Physiology)]. São Paulo: Instituto de Ciências Biomédicas, da Universidade de São Paulo; 2012.

Communication in the nervous system can occur directly between the cells through structures known as gap junction (GJ) channels. These channels allow the passage of small molecules up to $1 \mathrm{kDa}$ and are composed of protein subunits named connexins (Cxs). Cell communication through GJ plays an important role during the development and visual signaling. Furthermore, cell coupling provided by the GJs has been related to processes of survival/cell death. Similarly, in addition to the classic role of cyclins and cyclins dependent kinases (CDKs) in the cell cycle regulation and differentiation, they are also involved in neurodegenerative processes. Recent studies have demonstrated the reentry of apoptotic post mitotic neurons in the cell cycle. In this context, we analyzed the gene and protein expression of Cxs and cyclins after lesions in the visual system, specifically in the retina. For this purpose, a mechanic trauma was induced in the retina, which represents a model that allows us to visualize the lesion focus, penumbra and adjacent areas. Using combined techniques, such as the real time polymerase chain reaction (real-time PCR), Western blot and immunohistochemistry, we evaluated the spatio-temporal expression of these genes and their encoded proteins at different times post-lesion. The real-time PCR revealed no modulation of the Cx36 gene expression for all the times post-lesion analyzed. Our results showed increase in the Cx43 transcripts one, three and seven days post-lesion. The immunohistochemistry analysis indicated redistribution of $\mathrm{Cx} 36$ in response to the lesion in different times. On the other hand, Cx43 presented evident increased expression in the focus and penumbra areas of the lesion one, three and seven days post-lesion. In our experiments we could observe that cyclin D1 is expressed in cells located close to the lesion focus one and three days post-lesion, while cyclin B1 is expressed in these cells only one day post-lesion. The Western blot analysis did not show changes on the protein levels evaluated in this study in any of the post-lesion times analyzed. Data obtained from this study suggest i) the cells affected by the lesion are possibly coupled by GJ; ii) these cells express protein regulators of cell cycle. Altogether, the results indicate that it is possible to induce or prevent the reentry of post mitotic cells of the retina in the cell cycle, by controlling cell coupling provided by GJ.
\end{abstract}

Keywords: Retina. Gap junctions. Cyclins. Cell cycle. Neurodegeneration. 


\section{LISTA DE ILUSTRAÇÕES}

Figura 1 - Esquema simplificado da retina de vertebrados.....................................17

Figura 2 - Classificação dos canais e conexônios …………………………….......20

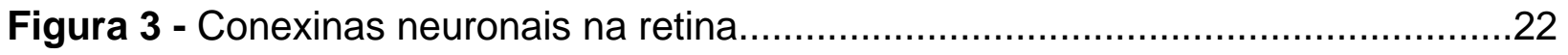

Figura 4 - Concentração das ciclinas durante as diferentes fases do ciclo celular.......24

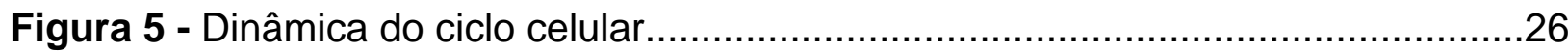

Figura 6 - Experimento com diferentes quantidades de cDNA (5, 10, 20 e $40 \mathrm{ng})$ utilizando primers para $\mathrm{C} \times 43$

Figura 7 - Curvas de dissociação obtidas através de nossos experimentos evidenciando a amplificação de produtos inespecíficos e produto único amplificado....37

Figura 8 - Sequência de nucleotídeos dos primers utilizados para análise da expressão gênica, através da técnica de PCR-Real time.

Figura 9 - Expressão gênica das Cx36 e Cx43 após lesão mecânica na retina de ratos

Figura 10 - Expressão gênica das ciclina D1 e B1 após lesão mecânica na retina de ratos.

Figura 11 - Níveis proteicos da C×36 na retina

Figura 12 - Níveis proteicos da Cx43 na retina

Figura 13 - Níveis proteicos da ciclina D1 na retina.

Figura 14- Análise da expressão de $C \times 36$ por microscopia confocal no modelo de lesão mecânica .50

Figura 15 - Análise da expressão de Cx43 por microscopia confocal no modelo de lesão m ecânica. 
Figura 16 - Análise da expressão de Cx43 e processos de astrócitos por microscopia confocal no modelo de lesão mecânica.

Figura 17 - Análise microscópica da Ciclina D1 métodos histoquímicos no modelo de lesão mecânica. .56

Figura 18 - Análise dos níveis proteicos de Ciclina D1 por métodos histoquímicos no modelo de lesão mecânica.

Figura 19 - Análise da expressão de ciclina D1 e processos de astrócitos por microscopia no modelo de lesão mecânica. .58

Figura 20 -Análise dos níveis proteicos de Ciclina B1 por métodos histoquímicos no modelo de lesão mecânica. 59

Figura 21 - Análise microscópica da Ciclina B1 métodos histoquímicos no modelo de lesão mecânica. 60

Figura 22 - Caracterização da morte celular por Fluoro-Jade B

Figura 23 - Caracterização da morte celular por apoptose utilizando a técnica de TUNEL

Figura 24 - Análise por microscopia confocal indicando possível relação da expressão de Cx36 e de células em morte celular por apoptose. 63 


\section{LISTA DE ABREVIATURAS E SIGLAS}

AMPc - adenosina monofosfato cíclico

APP - Proteína percursora amiloide

C - Celsius

$\mathrm{Ca}^{2}$ - Cálcio

CBX - Carbenoxolona

CDI - Cinases inibidoras de CDK

CDK - cinases

cDNA - complementar DNA

CIP/KIP - CDK interacting protein/Kinase inhibitory protein

Cx - Conexina

Cy5 - Cianina

DAPI - 4',6-diamidino-2-phenylindole, dihydrochloride

DNA - ácido desoxirribonucleico

G1 - fase gap 1

G2 - fase gap 2

GCL - camada de células ganglionares

GFAP - proteína ácida fibrilar glial

$\mathrm{HCl}$ - ácido clorídrico

IgG - Imunoglobulina $G$

INL - Camada nuclear interna

$\mathrm{Ip}_{3}-$ Inositol trifosfato

IPL - Camada plexiforme interna

JC - Junção Comunicante

$\mathrm{kDa}$ - Quilodalton

MAPK - Proteína cinase ativadora de mitose

mg - miligrama

$\mu \mathrm{L}$ - microlitros

$\mu \mathrm{m}$ - micrometros

mGluR - receptor metabotrópico glutamatérgico 


$$
\begin{aligned}
& \text { ml - mililitros } \\
& \text { mm - milimetros } \\
& \mathrm{mM} \text { - milimolar } \\
& \mathrm{NaCl} \text { - cloreto de sódio } \\
& \mathrm{NFL} \text { - camada nuclear interna } \\
& \mathrm{ng} \text { - nanograma } \\
& \mathrm{nm} \text { - nanômetro } \\
& \text { ONL - camada nuclear externa } \\
& \text { OPL - camada plexiforme externa } \\
& \mathrm{PB} \text { - tampão fosfato } \\
& \mathrm{PBS} \text { - salina tamponada } \\
& \mathrm{PCR} \text { - reação de polimerase em cadeia } \\
& \mathrm{PFA} \text { - paraformaldeído } \\
& \mathrm{PI} \text { - iodeto de propídeo } \\
& \mathrm{Rb} \text { - Proteína retinoblastoma } \\
& \mathrm{RNA} \text { - ácido ribonucleico } \\
& \mathrm{RNAm} \text { - RNA mensageiro } \\
& \text { RPE - epitélio pigmentado da retina } \\
& \text { rpm - rotações por minuto } \\
& \text { SNC - Sistema Nervoso Central } \\
& \text { Tm - temperatura de Melting } \\
& \text { TRITC - tetrametil isotiocianato de rodamina } \\
& \text { TTBS - solução basal } \\
& \text { TUNEL - dUTP nick end labeling }
\end{aligned}
$$




\section{SUMÁRIO}

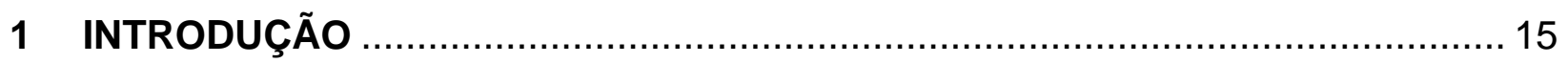

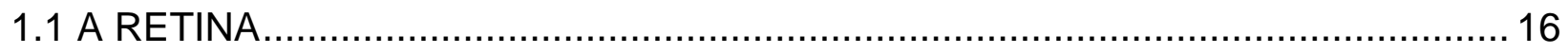

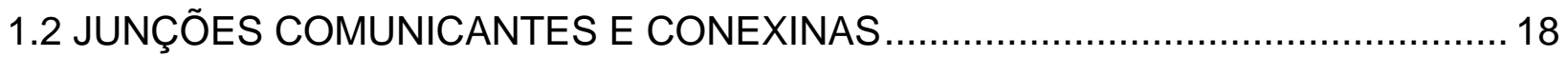

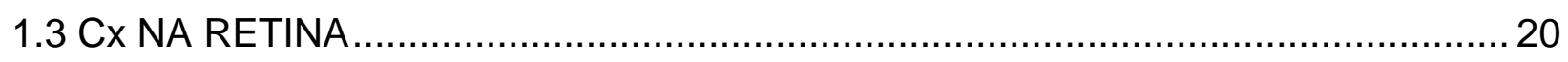

1.4 CICLO CELULAR E PROTEİNAS REGULADORAS DO CICLO CELULAR ............23

1.5 PROTEÍNAS REGULADORAS DO CICLO CELULAR EM PROCESSOS

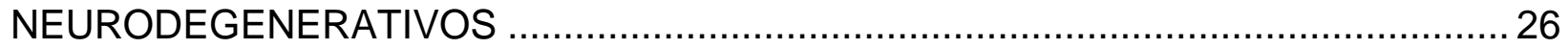

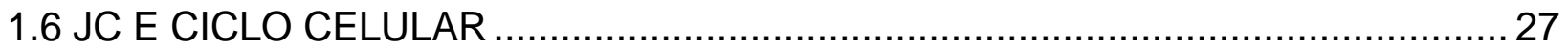

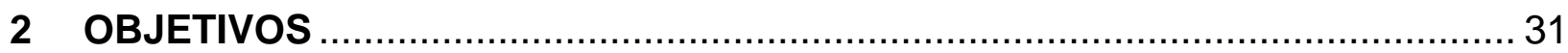

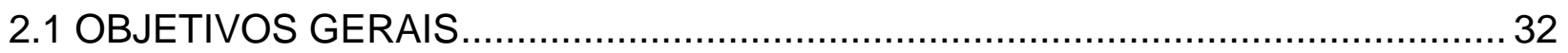

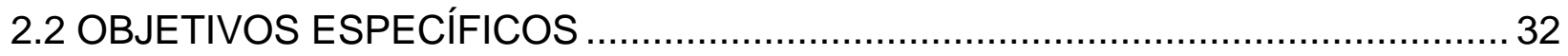

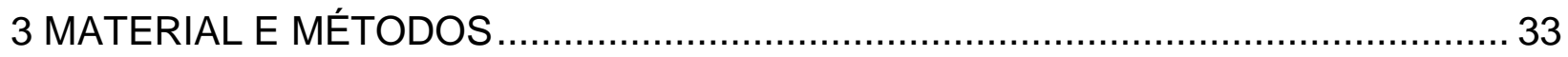

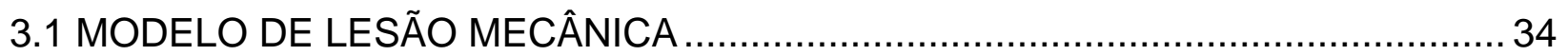

3.2 QUANTIFICAÇÃO DA EXPRESSÃO GÊNICA DAS Cxs E CICLINAS POR PCR

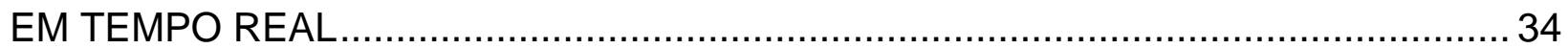

3.3 CARACTERIZAÇÃO DO PADRÃO DE EXPRESSÃO PROTEICA POR IMUNO-

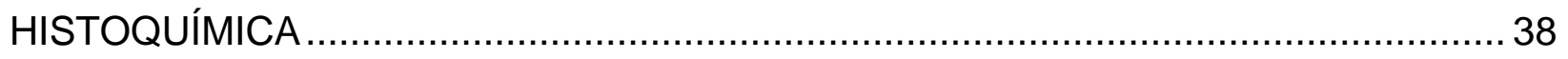

3.4 CARACTERIZAÇÃO MORFOLÓGICA DA RETINA EM DIFERENTES TEMPOS

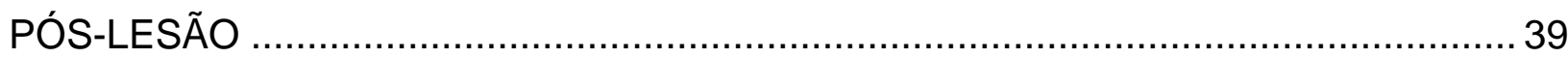

3.5 CARACTERIZAÇÃO DE MORTE CELULAR PROGRAMADA POR TUNEL........... 39

3.6 CARACTERIZAÇÃO DE MORTE CELULAR POR FLUORO-JADE B..................... 40

3.7 QUANTIFICAÇÃO DA EXPRESSÃO PROTEICA POR WESTERN BLOT ............. 41

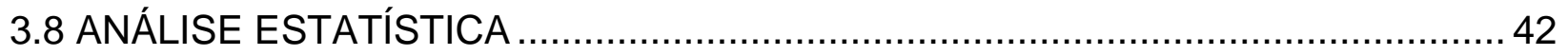

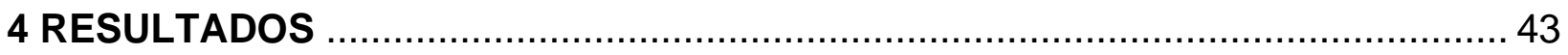


4.1 ANÁLISE DA EXPRESSÃO GÊNICA POR PCR REAL-TIME 44

4.1.1 Expressão gênica das Cxs 36 e 43 em diferentes tempos pós-lesão. .44

4.1.2 Expressão gênica das ciclinas D1 e B1 em diferentes tempos pós-lesão. 45

4.2 ANÁLISES DOS NÍVEIS PROTEICOS POR WESTERN BLOT. 46

4.2.1 Análises dos níveis proteicos das Cxs em diferentes tempos de exposição à lesão mecânica na retina. 46

4.3 AVALIAÇÃO DA MODULAÇÃO PROTEICA POR AVALIAÇÃO TECIDUAL. 48

4.3.1 A regulação da expressão proteica de Cxs é diferenciada durante o processo degenerativo 48

4.3.2 A regulação dos níveis proteicos da ciclina D1 e B1 é diferenciada durante o processo degenerativo. .55

4.3.3 Dinâmica da morte celular por necrose no presente modelo de neurodegeneração 60

4.3.4 Dinâmica da morte celular por apoptose no presente modelo de neurodegeneração.

4.3.5 Possível correlação da expressão de Cx36 e células em apoptose na degeneração da retina por trauma mecânico.

5 DISCUSSÃO 64

5.1 PREDOMÍNIO DA MORTE CELULAR SECUNDÁRIA EM RETINAS LESADAS ... 65

5.2 A CX36 ESTÁ PRESENTE EM CÉLULAS APOPTÓTICAS .....................................66

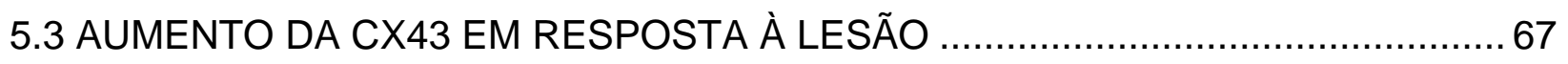

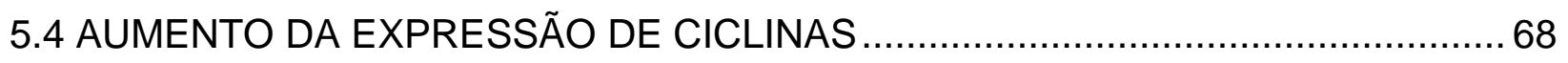

5.5 INDUÇÕES DA REENTRADA NO CICLO CELULAR NAS CÉLULAS DA RETINA PELA LESÃO NÃO GERA DIMINUIÇÃO NA EXPRESSÃO DE CONEXINAS ...............70

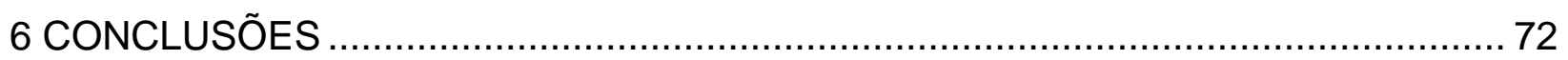

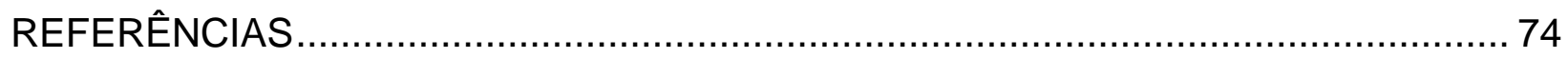




\subsection{A RETINA}

A retina é responsável pelo início do processamento da informação luminosa. Diferentemente de outras estruturas sensoriais, como a cóclea e os receptores somáticos da pele, a retina é considerada uma estrutura pertencente ao sistema nervoso central. Sua estrutura morfofuncional é bem caracterizada, apresentando um padrão de organização sináptica semelhante, porém simplificado, de outras regiões encefálicas centrais (Kandel et al., 2003).

A retina é uma estrutura formada por camadas alternadas de corpos e processos celulares, sendo estas constituídas por apenas cinco tipos básicos de neurônios e três tipos de células gliais. Essas células encontram-se organizadas nas diferentes camadas da retina, contribuindo de diferentes formas no processamento da informação visual.

O processamento visual inicia-se quando o estímulo luminoso atinge o segmento externo dos fotorreceptores, ocorrendo à transdução do sinal eletromagnético para o sinal eletroquímico. Esse sinal atinge o corpo celular, localizado na camada nuclear externa, e posteriormente os processos dos fotorreceptores, localizados na camada plexiforme externa. O sinal gerado pelos fotorreceptores é transmitido, através de sinapses, para as células bipolares, cujos pericários encontram-se localizados na camada nuclear interna. De forma similar, o sinal se propaga pelas células bipolares, atingindo seus processos localizados na camada plexiforme interna, onde ocorre a transmissão para processos pertencentes às células ganglionares, cujos corpos celulares estão localizados na camada de células ganglionares da retina (Kandel et al., 2003).

De forma resumida, a informação gerada pela transdução do estímulo eletromagnético nos fotorreceptores se propaga de forma vertical, por três tipos celulares ordenados em série na retina (fotorreceptores, células bipolares e células ganglionares), podendo ocorrer modulação horizontal pelas células horizontais (nas sinapses entre fotorreceptores e células bipolares) e pelas células amácrinas (nas sinapses entre células bipolares e ganglionares). Os pericários das células responsáveis pela modulação dos sinais propagados na retina estão localizados na camada nuclear interna, estando os pericários das células horizontais dispostas na 
margem externa dessa camada, e os corpos celulares das células amácrinas alocados em sua margem interna (Figura 1) (Webvision, 2012).

Figura 1 - Esquema simplificado da retina de vertebrados

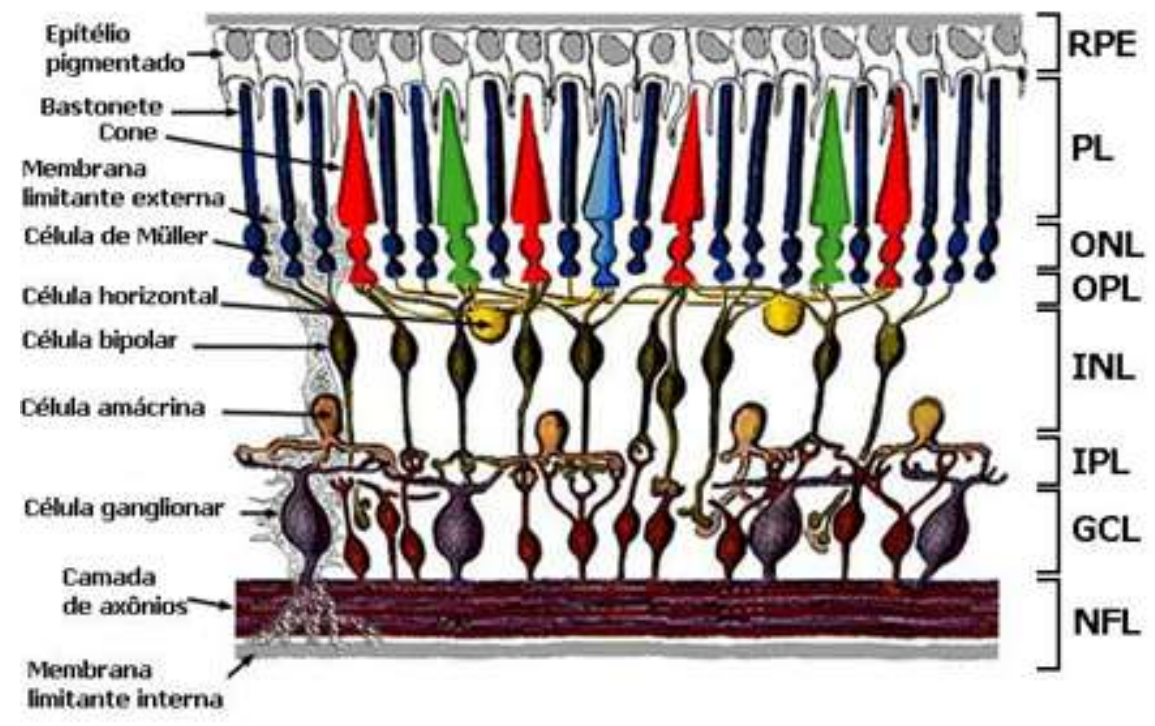

Esse modelo apresenta os principais tipos de células e sua organização em camadas da retina. RPE, epitélio pigmentado da retina; PL, camada de fotorreceptores; ONL, camada nuclear externa; OPL, camada plexiforme externa, INL, camada nuclear interna; IPL, camada plexiforme interna; GCL, camada de células ganglionares; NFL, camada de axônios retinianos.

FONTE: Adaptado de Webvision (2012)

Além de neurônios, três tipos principais de células gliais constituem a retina. Entre elas, apenas duas são classificadas como neuroglias (ou macroglias), as células de Müller e os astrócitos. Os astrócitos da retina se localizam na camada de axônios das células ganglionares, enquanto as células de Müller atravessam toda a espessura da retina, com processos que se estendem desde a membrana limitante interna até a membrana limitante externa.

Os astrócitos localizados na retina revestem os vasos e processos das células ganglionares. Essa relação com ambas às estruturas sugere que esse tipo celular pode formar uma bainha para os processos das células ganglionares, atuando como parte da barreira hematoencefálica. Devido a sua relação com os vasos sanguíneos e as células ganglionares, os astrócitos podem prover fornecimento de glicose aos neurônios. Além disso, os astrócitos podem ter uma relevante importância na regulação homeostática de 
íons, como a manutenção dos níveis de potássio extracelular, e no metabolismo de neurotransmissores (Stone e Dreher, 1987).

As células de Müller, por sua vez, são as principais células gliais da retina, contribuindo para a manutenção estrutural do tecido. Essas células são responsáveis por envolverem grupos de processos neuronais nas camadas plexiformes, permitindo o isolamento dos processos em regiões não sinápticas. Além disso, as células de Müller apresentam uma série de funções vitais para a manutenção dos neurônios da retina. Entre essas funções está o fornecimento de glicose para as células neuronais, remoção de resíduos como o dióxido de carbono e amônia, remoção e metabolização de neuromediadores localizados no espaço extracelular (Thoreson e Witkovsky, 1999), e controle da homeostase de íons no ambiente sináptico, através da captação e redistribuição do potássio extracelular (Dreher et al., 1994).

O esquema descrito é simplificado e não contempla os diversos subtipos celulares e a disposição diferenciada de algumas células. Apenas entre as células amácrinas já formam descritos, aproximadamente, 30 subtipos morfologicamente distintos, que usam pelo menos oito neurotransmissores diferentes. Outra peculiaridade são neurônios que podem se encontrar deslocados, como células ganglionares e amácrinas, que são encontradas em camadas nucleares diferentes da habitual.

\subsection{JUNÇÕES COMUNICANTES E CONEXINAS}

As junções comunicantes (JC) são estruturas que permitem a comunicação intercelular, que ocorre através da comunicação direta entre o citoplasma de duas células vizinhas. As JCs são compostas por milhares de aglomerados de canais intercelulares, formados pelo acoplamento de dois hemicanais, também conhecidos como conexônios (Maeda e Tsukihara, 2011). Cada conexônio é formado por seis subunidades proteicas, que atravessam toda membrana citoplasmática, sendo denominadas conexinas (Cxs). As Cxs se arranjam de maneira a formar um poro central na estrutura final do conexônio (Unwine e Zampighi, 1980), por onde transitam moléculas com massa de aproximadamente um 1000 Dalton $(\mathrm{kDa})$, como adenosina monofosfato cíclica (AMPc), e inositol-1,4,5-trifosfato $\left(\mathrm{IP}_{3}\right)$, além de íons como o cálcio $\left(\mathrm{Ca}^{2+}\right)$. Além de formarem canais de $\mathrm{JCs}$, os conexônios formados pelas $\mathrm{Cxs}$ poderiam 
constituir unidades funcionais independentes, atuando na liberação de moléculas para o ambiente extracelular (Jiang e Gu, 2005; Spray et al., 2006).

Cada molécula de $\mathrm{Cx}$ atravessa a membrana citoplasmática quatro vezes, formando duas alças extracelulares ( $\mathrm{C} 1$ e $\mathrm{C} 2$ ), quatro domínios transmembrânicos (M1 a M4), e dois segmentos citoplasmáticos carboxi e amino terminais. Cada alça extracelular possui três resíduos de cisteínas, as quais realizam ligações dissulfido entre as alças extracelulares, sendo importantes para a formação de canais funcionais de JC (Bao et al., 2004).

De acordo com o comprimento e homologia da alça intracelular formada pelo segmento da molécula entre os domínios transmembrânicos M2 e M3, podemos classificar as conexinas como pertencentes a três diferentes grupos. Caso o segmento for curto, a Cx é classificada como sendo do grupo I, também conhecido como Cxs $\beta$; se o segmento for longo, como pertencente ao grupo II, ou Cx $\alpha$ (Bennett et al., 1991). Até o presente momento, somente a $\mathrm{C} \times 36$ foi classificada como pertencente ao grupo III $(\gamma)$. Cada Cx é nomeada de acordo com o peso molecular que apresenta (por exemplo, a Cx43 possui o peso molecular $43 \mathrm{kDa}$ ).

As diversas isoformas de Cxs apresentam propriedades fisiológicas e resposta a regulação de forma diferenciada. Os canais de JC podem ser constituídos por um único tipo de conexônio, sendo denominado homotípico, ou por dois diferentes tipos de conexônios, denominado heterotípico. Além disso, cada conexônio pode ser composto por diferentes Cxs ou pelo mesmo tipo de conexina, denominadas, respectivamente, conexônios heteroméricos e homoméricos (Bloomfield e Volgyi, 2009). Dessa forma, essa variedade de combinações proporciona uma diversidade na função e composição dos canais de JC (Maeda e Tsukihara, 2011). 
Figura 2 - Classificação dos canais e conexônios
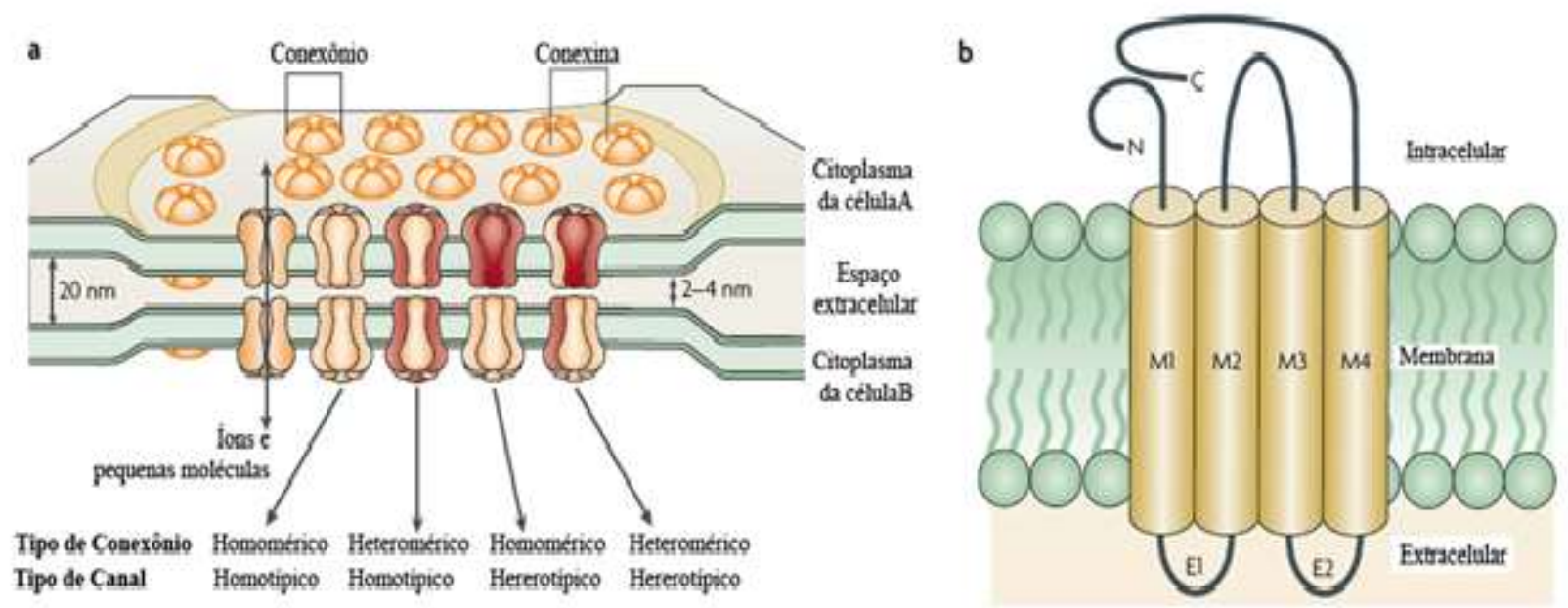

a) Os conexônios são classificados de acordo com as Cxs que as compõe. Conexônios formados por Cxs distintas são denominados heteroméricos. Conexônios formados pelo mesmo tipo de Cx são denominados homoméricos. Os canais de JC são classificados de acordo com os conexônios que os compõe. Canais formados por dois conexônios distintos são classificados como heterotípico. Canais formados pelo mesmo tipo de conexônios são classificados como homotípicos. b) As moléculas de Cx apresentam quatro domínios transmembrânicos (M1 a M4), e dois segmentos citoplasmáticos carboxi e amino terminais. As alças extracelulares (E1 e E2) possuem, cada uma delas, três resíduos de cisteínas, as quais realizam ligações dissulfido entre as alças extracelulares, sendo importantes para a formação de canais funcionais de $\mathrm{JC}$.

FONTE: Bloomfield et al. (2009)

\subsection{Cx NA RETINA}

Até o momento 14 Cxs (Cx26, Cx29, Cx30, Cx31, Cx32, Cx36, Cx37, Cx40, Cx43, Cx45, Cx46, Cx47, Cx50 e Cx57) foram identificadas e possuem variados níveis proteicos no sistema nervoso de mamíferos (Guldenagel et al., 2000). Na retina de roedores já foram detectados RNA mensageiro de Cxs: Cx31, Cx32, C×36, Cx37, Cx40, Cx43, Cx50 e Cx57. Por análise de Western Blot e imunofluorescência já foram detectadas as seguintes Cxs na retina de camundongos: Cx36, Cx37, Cx43, Cx45 e Cx57 (Sohl et al., 2000). A expressão da Cx36 é exclusivamente neuronal, sendo identificada sua presença em bastonetes (Dang et al., 2004), células bipolares (Feigenspan et al., 2004), amácrinas All (Mills et al., 2001), e células ganglionares (Hidaka et al., 2002). A Cx37 é tida como expressa apenas por endoteliócitos, enquanto a Cx43 é expressa por astrócitos (Guldenagel et al., 2000) e células de Müller (Kihara et al., 2006a). Particularmente interessante é a expressão da Cx45: enquanto alguns 
estudos sugerem que esta Cx seja exclusivamente neuronal (Guldenagel et al., 2000), outros trabalhos sugerem que seja também expressa por células gliais (Zahs et al., 2003). Finalmente, a $C x 57$ é, até o momento, a única $C x$ presente em um único tipo celular na retina: estudos com o gene repórter lacZ (Hombach et al., 2004) determinaram que a $\mathrm{C} \times 57$ é exclusivamente expressa por células horizontais, sendo sua quantidade e distribuição modulada por eventos sinápticos gerados a partir dos fotorreceptores (Kihara et al., 2008). A plasticidade da expressão de Cx, durante a histogênese da retina, sugere que exista uma especificidade espacial/temporal da comunicação por elas mediada (Becker et al., 2002), com papel destacado para as Cx43 (Pearson et al., 2004) e Cx45 (Kihara et al., 2006b, 2010). A expressão diferenciada de Cxs resulta em canais funcionalmente distintos que poderiam influenciar na difusão de moléculas sinalizadoras específicas (Lo, 1996). 
Figura 3 - Conexinas neuronais na retina

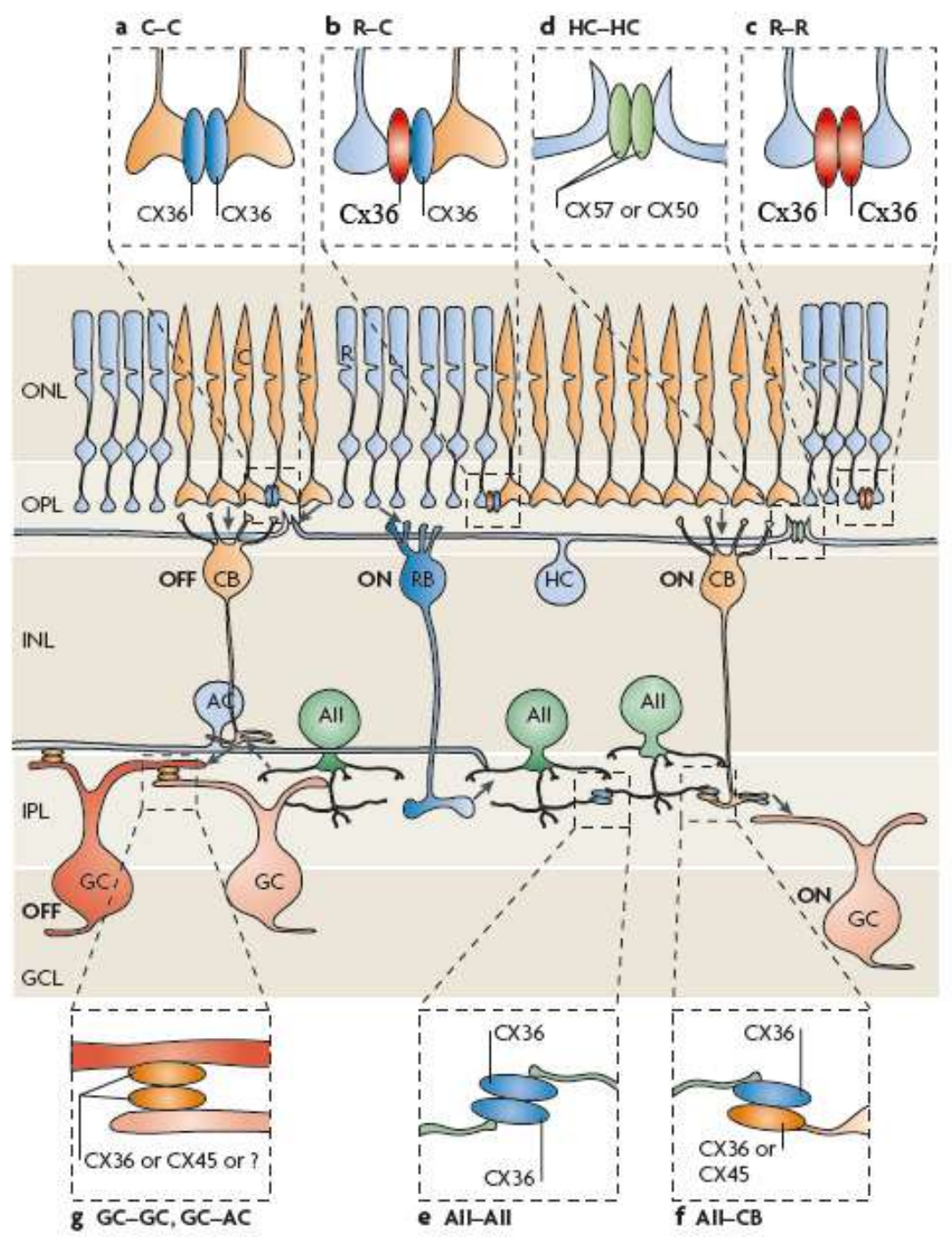

As representações ovais de diferentes cores correspondem a hemicanais de JC. (a) Ambos hemicanais de JCs responsáveis pelo acoplamento entre cones (C) expressam Cx36. (b) Nas JCs entre cones e bastonetes (R), os hemicanais do lado do cone são formados pela Cx36, (c) assim como do lado dos bastonetes. (d) Dendritos de células horizontais $(\mathrm{HC})$ são altamente acopladas. Em mamíferos, diferentes tipos de células horizontais expressão Cx50 e Cx57. (e, f) Células amácrinas All (All) formam dois tipos de JCs, sendo esses homotípicos e seus conexônios homoméricos contendo Cx36. Por sua vez, JCs entre All e células cone bipolares ON (CB) podem ser homotípicos ou heterotípico, sendo que os conexônios das All são compostos pela CX36 e das CB formados por CX36 e Cx45. (g) Células ganglionares (GC) são extensivamente acopladas entre si ou com células amácrinas ( $A C)$ vizinhas. As GC apresentam JCs compostas Cx36 e Cx45. GCL; camada de células ganglionares; INL, camada nuclear interna; IPL, camada plexiforme interna; ONL, camada nuclear externa; OPL, camada plexiforme externa; RB, célula bipolar acopladas com cones.

FONTE: Bloomfield e Völgyi (2009)

Na retina, além de elemento essencial na sinalização visual (Deans et al., 2002), e de participar dos processos de adaptação aos diferentes níveis de luminosidade 
(Becker et al., 1998; Kihara et al., 2006a, b), a comunicação mediada por Cxs desempenha papel destacado na histogênese retiniana, processos como apoptose (Cusato et al., 2003; Linden, 2000) e propagação da sinalização mediada pelas ondas de $\mathrm{Ca}^{2+}$ (Roerig e Feller, 2000).

\subsection{CICLO CELULAR E PROTEÌNAS REGULADORAS DO CICLO CELULAR}

O ciclo celular é caracterizado por uma série de eventos que levam ao aumento celular, replicação do DNA, segregação cromossômica e a criação de duas células filhas a partir da célula mãe original. $O$ ciclo celular consiste em quatro diferentes fases: G1, S, G2, e a fase M. A fase G1 é um período de crescimento e preparação para a divisão, é nesta fase que a célula cresce em volume. A fase $S$ é onde a maquinaria de síntese da replicação do DNA duplica o número de cromossomos. A fase G2 é onde a célula está se preparando para a divisão. Finalmente, durante a fase $M$ é onde ocorre a mitose de fato, ou seja, quando a célula se divide formando duas células filhas (Yang e Herrup, 2007).

Esse importante processo biológico é orquestrado pela expressão, ativação e inativação de proteínas reguladoras do ciclo celular, incluindo ciclinas, cinases dependentes de ciclinas (CDK), e inibidores de cinases dependentes de ciclinas (CDI). Membros da família das CDKs são constituídos de pequenas proteínas, serina/treonina cinases (30-35 kDa). As CDKs são numeradas na ordem em que foram descobertas, começando com a CDK1 (p34cdc2) e se estendendo até a CDK9 (Nguyen et al., 2002). As CDls são compostas por duas famílias distintas de proteínas, a Cip/Kip e INK4, as quais agem se ligando e, por consequência, inativando as CDKs. A família Cip/Kip das CDIs interage com uma ampla gama de complexos ciclina-CDK, enquanto os membros da família INK4 agem inibindo especificamente as CDK4 e CDK6 (Wang et al., 2009).

As CDKs apresentam modulações em sua atividade, de acordo com a fase do ciclo celular. As oscilações de atividade das CDKs levam diretamente a mudanças cíclicas na fosforilação de proteínas intracelulares, que iniciam ou regulam os principais eventos do ciclo celular - replicação do DNA, mitose e citocinese. As CDKs, como seu próprio nome diz, são dependentes de ciclina para sua ativação, sendo que seus níveis de concentração apresentam-se constantes durante os diferentes estágios do ciclo 
celular. Já as ciclinas foram assim denominadas por sofrerem um ciclo de síntese e degradação em cada ciclo celular, ocorrendo variações em seus níveis de concentração (Lwis et al., 2004).

Figura 4 - Concentração das ciclinas durante as diferentes fases do ciclo celular

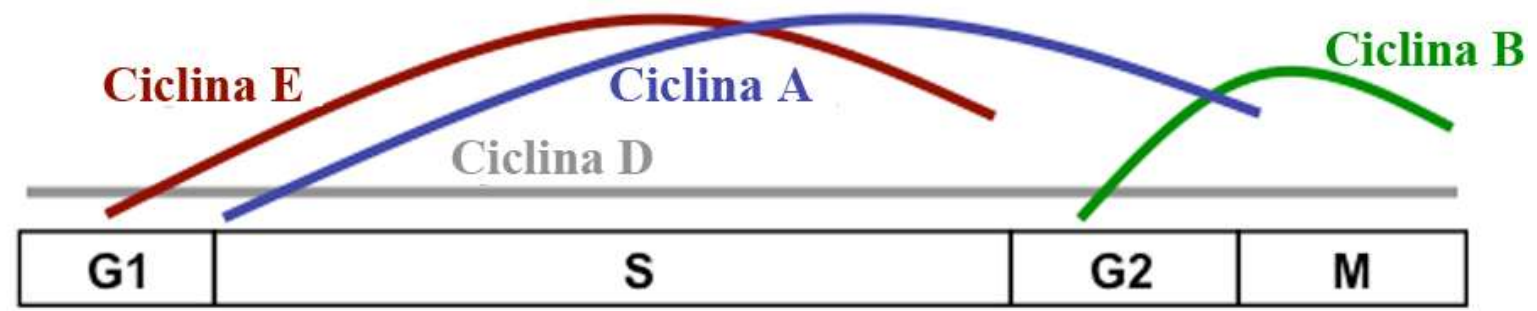

As ciclinas D, E e A são sintetizadas na fase $G 1$ do ciclo celular, e são degradas na fase $M$, fase $S$ e fase $M$, respectivamente. A ciclina $B$ é sintetizada na fase $S$ do ciclo celular, e também é degradada na fase M.

FONTE: Coklin e Sage (2009)

Nas células de mamíferos, a progressão do ciclo celular é iniciada pelo aumento da expressão de ciclinas da família $D$, fato desencadeado por estímulos mitóticos. A ciclina $D$ age como um sensor de ativação da maquinaria do ciclo celular, levando a célula a iniciar a fase G1. As ciclinas da família D interagem com as CDK4 e/ou 6 formando o complexo ativo ciclina D-CDK4/CDK6. O complexo ciclina D-CDK4/CDK6 age fosforilando a proteína supressora tumoral retinoblastoma $(R b)$ resultando na liberação da molécula E2F. Essa molécula atua no DNA estimulando a transcrição de genes específicos. A fosforilação da Rb é considerada o ponto crítico de ativação do ciclo celular, já que a partir disso, a célula é acometida a entrar na fase $S$, independentemente da presença ou ausência de estímulos extracelulares (Pardee, 1989). No final da fase $G 1$, as CDK2 são ativadas por ciclinas da família $E$, em consequência do aumento de sua expressão. O complexo Ciclina E-CDK2 auxilia nos processos de replicação do DNA, que são silenciados na fase $S$ para evitar nova replicação do DNA (Malumbres e Barbacid, 2005). A inativação do complexo é dada pela rápida degradação da ciclina $E$ por complexos enzimáticos específicos. Em consequência da diminuição da quantidade de ciclina e pelo aumento progressivo da 
ciclinas da família $A$, as CDK2 são ativadas pelas ciclinas do tipo A no final da fase $S$. O complexo ciclina A- CDK2 é conhecido por fosforilar diversas proteínas que realizam a progressão adequada da sequência de eventos, existentes no término da fase $S$ e, consequentemente, para a transição para a fase G2.

$\mathrm{Na}$ fase G2, o complexo ciclina A- CDK2 é inativada pela degradação progressiva da ciclina A por ubiquitinação. Enquanto esse processo ocorre, as ciclinas da família B são ativamente sintetizadas. Os níveis da ciclina B1 aumentam durante o período final da fase $\mathrm{S}$, persistindo até o início da fase $\mathrm{G} 2$. $\mathrm{O}$ aumento das ciclinas da família $B$ contribui para sua interação com as CDK1, evento essencial para desencadear a mitose. A formação de complexos ciclina B1-CDK1 provoca sua acumulação no citoplasma (Pines, 1993). Devido à fosforilação em sequências específicas, responsáveis pela retenção citoplasmática do complexo ciclina B-CDK1, esse complexo pode ser translocado para o núcleo da célula. No núcleo, o complexo ciclina B-CDK1 auxilia na condensação cromossomal e quebra da membrana nuclear (Li et al., 1997). Ao aproximar do ponto de checagem, a perda progressiva de atividade do complexo ciclina B-CDK1 é essencial para que ocorra a segregação cromossomal e a subsequente divisão celular da forma devida (Pines, 2006).

Essa descrição é resumida e não contempla a atuação das CDIs na regulação do ciclo celular. A rede intrincada de eventos é baseada em processos de ativação e inibição de moléculas sinalizadoras da progressão do ciclo celular. Esse processo utiliza alças de regulação retroativas, positivas e negativas, para proporcionar o devido controle dinâmico do ciclo celular. 
Figura 5 - Dinâmica do ciclo celular

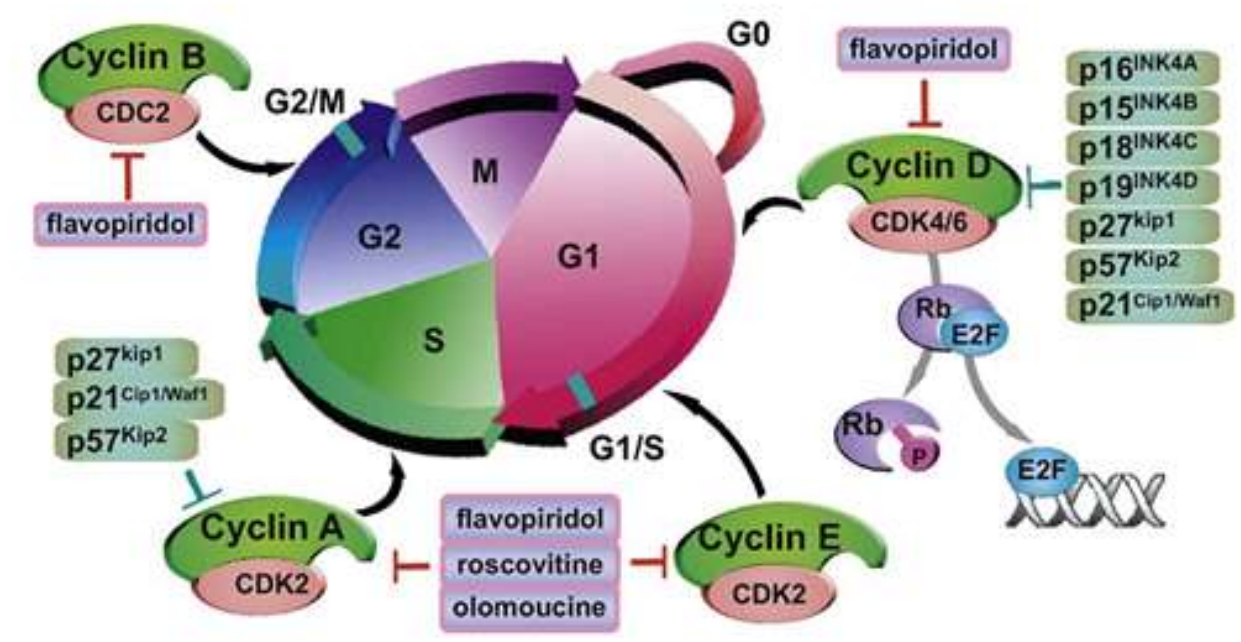

O ciclo celular passa pelas fases G0, G1, S, G2 e M para completar a divisão celular. A progressão é regulada pela expressão e ativação das proteínas do ciclo celular, incluindo ciclinas, CDKs e CDIs. O ciclo celular se inicia pela elevação da ciclina $D$, que interage com as CDK4 e CDK6 formando o complexo ciclina D- CDK4/6 que age fosforilando a Rb e liberando a E2F, evento que ativa a transcrição do DNA. A progressão do ciclo celular pode ser bloqueada pela ação de inibidores endógenos, membros das CDIs, e por alguns bloqueadores exógenos, que atuam em diferentes pontos do ciclo celular. FONTE: Wang et al. (2009)

\subsection{PROTEÍNAS REGULADORAS DO CICLO CELULAR EM PROCESSOS NEURODEGENERATIVOS}

A progressão do ciclo celular é dada pela ativação e inativação coordenada de determinadas proteínas de regulação. A desregulação da maquinaria do ciclo celular geralmente acarreta em disfunções que podem levar a célula a iniciar o processo de apoptose.

Além da visão intuitiva da desregulação do ciclo celular estar relacionada com processos oncogênicos, um número crescente de estudos tem apontado que a ativação inapropriada de elementos do ciclo celular em células neuronais apresenta um papel importante em diversas doenças do sistema nervoso central.

Os neurônios são células altamente diferenciadas que se encontram na fase G0 do ciclo celular, porém estudos vêm demonstrando que neurônios pós-mitóticos reentram no ciclo celular em circunstâncias patológicas. A indução de ciclinas da família $\mathrm{D}$ induz à reentrada no ciclo celular, e é geralmente considerada como um indicador de 
morte celular programada (Kranenburg et al., 1996). A expressão de diferentes moléculas do ciclo celular tem sido encontrada como precedente da morte excitotóxica em vários modelos experimentais (Nguyen et al., 2002). Por exemplo, em casos de isquemia cerebral (Guegan et al., 1997; Katchanov et al., 2001) e de epilepsia, ocorre o aumento da expressão de ciclinas D1 nas células neuronais. Estudos de danos isquêmicos em retinas de ratos demonstraram elevação das concentrações de ciclina D1 em neurônios apoptóticos e em células de Müller (Kuroiwa et al., 1998). Além disso, a diminuição da expressão de inibidores de CDK tem sido encontrada como precedente de morte neuronal (Krantic et al., 2005).

Em processos degenerativos agudos no Sistema Nervoso Central (SNC), a indução da reentrada do ciclo celular, gerada pela ativação do complexo ciclina DCDK4/6 acarreta a fosforilação da Rb e a subsequente liberação da E2F, é bloqueada entre as fases $\mathrm{G} 1$ e $\mathrm{S}$ do ciclo celular.

Porém, em desordens neurodegenerativas crônicas, tais como em modelos de Doença de Parkinson e Alzheimer, alguns neurônios podem prosseguir até a fase $S$ do ciclo celular. Após a duplicação do DNA, a maquinaria do ciclo celular leva os neurônios a entrarem na fase de transição G2/M. Nessa fase a CDK1 e a ciclina B1 são altamente expressas e ativas, porém se encontram deslocadas, se situando no citoplasma. $\mathrm{O}$ complexo ciclina B-CDK1 age fosforilando proteínas do citoesqueleto celular, como a proteína percursora amiloide (APP). Por esse motivo, os neurônios não progridem para a fase $\mathrm{M}$ e acabam entrando em apoptose (Wang et al., 2009).

\subsection{JC E CICLO CELULAR}

A atividade das proteínas reguladoras do ciclo celular depende do comando determinado por sinais extracelulares, incluindo as comunicações parácrina e sináptica. Com relação a esta última, maior atenção tem sido dada a sinapse química, com ênfase para sistemas de neurotransmissão específicos, como o colinérgico. No entanto, recentes estudos têm mostrado que a regulação do ciclo celular e da comunicação intercelular mediada pelas JCs ocorre em diferentes eixos de interação.

Em experimentos realizados com hepatócitos, verificou-se o aumento transitório da quantidade de JCs na fase G1 do ciclo celular, seguida de uma drástica diminuição 
na fase $S$, resultante de variação da expressão gênica de Cxs específicas (Vinken et al., 2011). A modulação da expressão de algumas Cxs também é observada na indução da regeneração muscular através de diferentes tipos de lesões musculares em ratos (Gorbe et al., 2005, 2006; Trovato-Salinaro et al., 2009), e em células proliferativas do neocortex de roedores (Bittman et al., 1997; Bittman e LoTurco, 1999). Estes estudos demonstram que alterações nos padrões das JCs e a expressão de diferentes Cxs durante o ciclo celular em células somáticas, tanto em condições patológicas quanto em condições fisiológicas, exibem uma relação inversa entre a proliferação celular e a atividade das JCs (Vinken et al., 2011).

Os mecanismos que envolvem a modulação da expressão gênica das Cxs podem estar atrelados a cascatas de sinalização, que regulam o ciclo celular. Diversas vias de sinalização relacionadas à proliferação celular são conhecidas por afetar a transcrição gênica de Cxs, como a via de transdução da sinalização da proteína cinase ativadora de mitose (MAPK). As diferentes cascatas de sinalização que compõe a via de sinalização da MAPK, caracterizadas em mamíferos, podem ser ativadas por uma série de estímulos extracelulares, como hormônios e fatores de crescimento, influenciando na transcrição de genes relacionados ao ciclo celular, devido à fosforilação de pro-oncogênes como c-jun e c-fos (Kim e Choi, 2010; Krishna e Narang, 2008). Com a indução das MAPK, algumas proteínas podem ser desimpedidas de interagir com a região promotora de genes responsáveis pela expressão de Cxs específicas. (Carystinos et al., 2003; Oyamada et al., 2005).

Além da modulação da expressão de Cxs, outra importante via de regulação da sinalização relacionada às JCs é a fosforilação de Cxs durante o ciclo celular. Estudos têm demonstrado que os complexos enzimáticos formados durante a progressão do clico celular podem atuar na fosforilação das Cxs formadoras das JC, interferindo no fluxo de informações entre as células acopladas. O complexo ciclina B-CDK1, em diferentes tipos celulares, é responsável pela fosforilação da Cx43 durante a fase de transição G2/M do ciclo celular, fazendo com que a forma fosforilada da Cx43 se localize, de preferência, no citoplasma, reduzindo assim a atividade das JCs observadas em células mitóticas (Vinken et al., 2011). Outras moléculas relacionadas à regulação do ciclo celular também são conhecidas por fosforilar diretamente as JCs, 
como a MAPK, proteína que além de regular a transcrição das Cxs também está envolvida na fosforilação dessas proteínas (Kojima et al., 2004; Yamamoto et al., 2005).

A via de sinalização direta entre as células mediada pelas JCs está diretamente envolvida na regulação do ciclo celular. Diversos estudos utilizando bloqueadores químicos das JCs têm demonstrado que esta via de troca direta entre as células afeta 0 ciclo celular. Estudos utilizando carbenoxolona (CBX) em retinas de rato demonstraram que o bloqueio das JC da retina in vivo leva a supressão da atividade mitótica das células da retina, durante o desenvolvimento (Kihara et al., 2010). A utilização de bloqueadores de JCs altera a síntese de DNA em cultura de células estreladas hepáticas, acompanhadas por uma diminuição da expressão da ciclina D1, ciclina D2, CDK2, CDK4, CDK6 (Uyama et al., 2003). Em cultura de astrócitos de ratos, as células expostas ao CBX apresentaram aumento da quantidade de células nas fases $\mathrm{S}$, G2 e M do ciclo celular, e diminuição simultânea da quantidade de células nas fases G1 e G0 do ciclo celular. Esse fato é atrelado ao aumento da fosforilação da $\mathrm{Rb}$ e ao aumento da expressão de ciclina D1 e D3 (Tsutsumi et al., 2009).

Tais evidências apontam para o fato de que as JCs funcionam como uma via de troca intercelular direta de moléculas ou íons, que regulam positivamente e/ou negativamente o crescimento celular. Porém, a identidade bioquímica das moléculas relacionadas a esses eventos ainda necessita ser elucidada. O AMPc, segundo mensageiro que atravessa as $\mathrm{JCs}$, é conhecido por aumentar a produção da p27 $7^{\mathrm{KIP} 1}$ (Zhang et al., 2003a, b). A concentração do AMPc é maior na fase G1, diminuindo primeiramente na entrada da fase S (Stork e Schmitt, 2002), evento que está correlacionado com a diminuição do acoplamento celular na fase de transição G1/S do ciclo celular, observado em diferentes tipos celular.

O cálcio também é um candidato plausível para mediar a regulação intracelular no fenômeno conhecido como ondas de cálcio (calcium waves), que ocorrem através da passagem direta de cálcio entre as células, ou pela passagem de segundos mensageiros que desencadeiam a liberação dos estoques intracelulares de cálcio, como $\circ \mathrm{IP}_{3}$. Estudos realizados com bloqueadores de JCs demonstraram que estas substâncias, em altas concentrações, impedem a propagação das ondas de cálcio e, 
em baixas concentrações, diminuem seu domínio de ação (Stellwagen et al., 1999). Manipulações realizadas sobre as ondas de cálcio, em tecidos como a retina, afetam o desenvolvimento da circuitaria visual, indicando que esta atividade espontânea apresenta um papel fundamental em processos dependentes de atividade durante 0 desenvolvimento do sistema visual (Feller, 2002; Wong, 1999). Quando a concentração intracelular de cálcio aumenta, diversas vias intracelulares são ativadas, podendo induzir a transcrição de genes relacionados ao controle do ciclo celular.

Apesar de alguns modelos de indução de processos neurodegenerativos apontarem que as células afetadas secundariamente permanecem acopladas através das $\mathrm{JC}$, não há estudos que contemplem a relação dessa via de sinalização com a indução ou regulação da reentrada do ciclo celular em neurônios pós-mitóticos. 
2 OBJETIVOS 


\subsection{OBJETIVOS GERAIS}

Visto o papel das JCs na sobrevivência/morte neuronal, e a importância das proteínas reguladoras do ciclo celular durante processos neurodegenerativos, nossos objetivos são: 1) determinar a modulação da expressão gênica e proteica das Cxs envolvidas na comunicação intercelular, entre astrócitos e neurônios, e das ciclinas após lesão mecânica na retina; 2) avaliar o papel do acoplamento celular provido pelas JCs sobre a expressão gênica e proteica das ciclinas, durante a neurodegeneração da retina.

\subsection{OBJETIVOS ESPECÍFICOS}

- Analisar por imuno-histoquímica o padrão temporal da expressão proteica das Cx36 e Cx43, e das ciclinas D1 e B1 na retina de ratos (Rattus novergicus), após lesão mecânica;

- quantificar por PCR em tempo real os níveis de RNAm das Cx36 e Cx43, e das ciclinas D1 e B1 na retina de ratos após lesão mecânica;

- quantificar por Western Blot os níveis proteicos das Cx36 e Cx43, e da ciclina D1 na retina de ratos após lesão mecânica. 


\section{MATERIAL E MÉTODOS}




\subsection{MODELO DE LESÃO MECÂNICA}

Foram utilizados ratos (Rattus norvegicus) Long-Evans adultos, com 45-60 dias de vida, provenientes do Biotério de Anatomia do Instituto de Ciências Biomédicas da Universidade de São Paulo. Os animais foram mantidos em temperatura controlada (20$22^{\circ} \mathrm{C}$ ) e ciclo claro/escuro de 12 horas. Receberam alimentação balanceada e água ad libitum. Todos os procedimentos experimentais, que incluem a indução da lesão na retina dos ratos, foram realizados de acordo com as normas do Comitê de Ética em Experimentação Animal do Instituto de Ciências Biomédicas da Universidade de São Paulo. Após anestesiar os animais com $10 \mathrm{mg} / \mathrm{Kg}$ de cloridrato de xilazina e $200 \mathrm{mg} / \mathrm{kg}$ de cloridrato de ketamina, os olhos dos roedores foram submetidos a lesões por meio de uma agulha hipodérmica $(13 \times 4,5 \mathrm{~mm})$. Durante este procedimento, a agulha atravessa à córnea, cristalino, humor vítreo, retina, epitélio pigmentado e esclera. Após a indução da lesão, os animais foram sacrificados nos intervalos de duas e seis horas, um, três e sete dias. Ao serem decapitados, os animais tiveram os olhos retirados e, quando necessário, as retinas dissecadas para posterior aplicação das diferentes metodologias.

\subsection{QUANTIFICAÇÃO DA EXPRESSÃO GÊNICA DAS CXs E CICLINAS POR PCR EM TEMPO REAL}

Para avaliação do padrão temporal de expressão dos genes estudados, a técnica de lesão foi executada em apenas um dos olhos dos roedores, utilizando o olho contralateral do animal como controle. Foram utilizados entre quatro a seis animais para formação dos diferentes grupos, determinados pelo tempo de exposição à lesão e seus respectivos controles.

As retinas dissecadas foram isoladas e condicionadas em $500 \mu \mathrm{L}$ do reagente TRIzol® (Invitrogen, Carlsbad, CA, EUA). Após esse procedimento, as retinas foram maceradas com o auxílio de um sonicador. Ao material resultante foram adicionados $100 \mu \mathrm{L}$ de clorofórmio e as amostras foram centrifugadas (12000 rpm a $4{ }^{\circ} \mathrm{C}$ ) durante 15 minutos. A fase translúcida superficial, resultante do processo de centrifugação, foi separada e condicionada em tubos $(1,5 \mathrm{~mL})$ e, posteriormente, foram adicionados 250 $\mu \mathrm{L}$ de isopropanol. As amostras foram centrifugadas (10000 rpm a $4^{\circ} \mathrm{C}$ ) por 10 minutos 
e o resíduo sobrenadante foi descartado. Ao precipitado de RNA foi adicionado 1,0 mL de etanol $(75 \%)$, e as amostras centrifugadas $\left(7500 \mathrm{rpm}\right.$ a $4{ }^{\circ} \mathrm{C}$ ) por 10 minutos. Os resíduos sobrenadantes foram descartados, preservando no tubo apenas o precipitado de RNA. A esse material foi adicionado $20 \mu \mathrm{L}$ de água livre de Nucleases (Promega, EUA) e, posteriormente, homogeneizado. A concentração do RNA total foi quantificada por espectrofotometria, utilizando $260 \mathrm{~nm}$ de comprimento de onda. De forma prévia a realização do protocolo de transcrição reversa, as amostras foram tratadas com DNAse Amplification Grade (Invitrogen, EUA) e, posteriormente, a enzima M-MLV (Invitrogen, EUA) para realização da transcrição reversa. Para ambos os procedimentos adotamos o protocolo fornecido pelo fabricante (Invitrogen, EUA).

Para os estudos de quantificação de expressão gênica realizamos experimentos utilizando o PCR em tempo real (Rotor-Gene Q, Qiagen). Neste sistema, a amplificação da sequência alvo é detectada em tempo real pela emissão de fluoróforo, que ocorre quando há formação de dupla fita na região codificada pelo par de primers. A quantificação da amplificação é feita pela fluorescência captada pela unidade óptica do aparelho (Figura 6). Pelas características do sistema, no PCR em tempo real, é possível determinar todo perfil de amplificação, o que representa uma de suas vantagens metodológicas (Kihara et al., 2005; Schmittgen et al., 2000). 
Figura 6 - Experimento com diferentes quantidades de cDNA (5, 10, 20 e $40 \mathrm{ng})$ utilizando primers para Cx43.

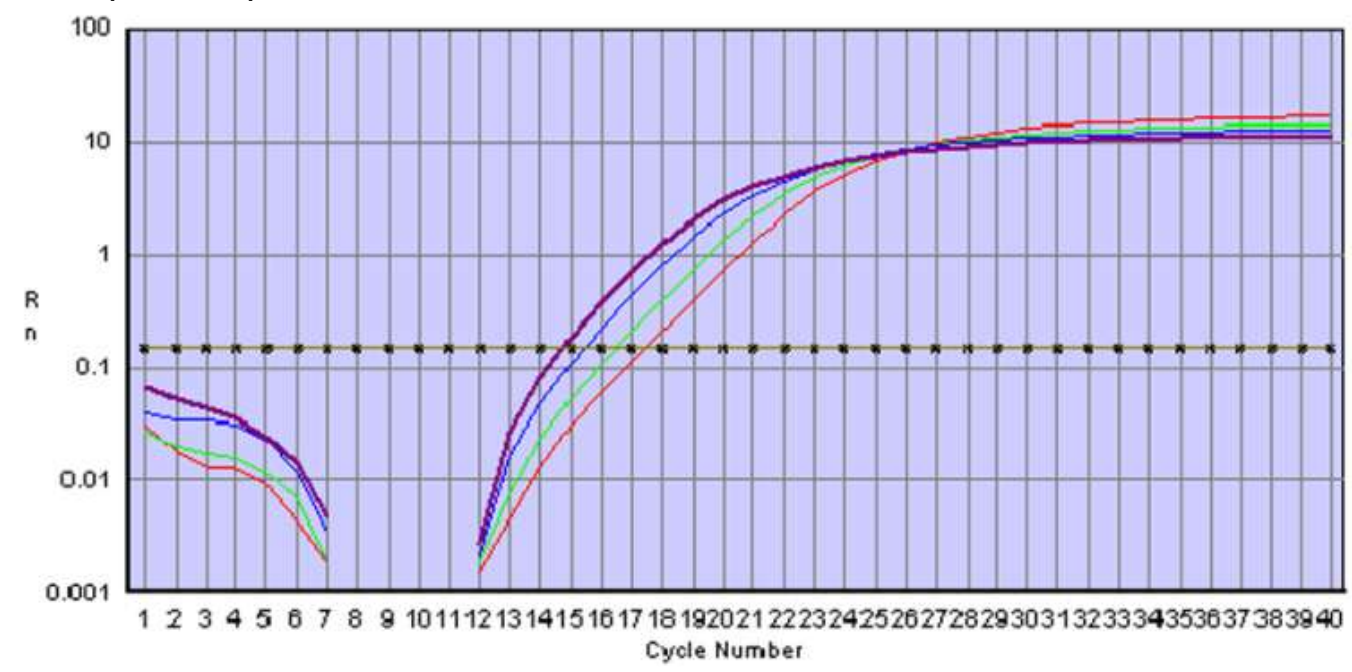

As curvas representam a fluorescência detectada pelo sistema (ordenada), em função do número de ciclos (abcissa). Quanto menor a quantidade inicial de cDNA, maior o número de ciclos necessários para se atingir o mesmo nível de fluorescência normalizada, ou seja, o mesmo número de cópias do fragmento amplificado (amplicon). FONTE: Higa (2012)

Para efetuarmos a experimentação por PCR em tempo real utilizamos o sistema SYBR Green, especificamente o reagente goTaq qPCR Master Mix (Prodimol, EUA), seguindo especificações de uso fornecidas pelo fabricante. Neste sistema, o fluoróforo está no tampão do PCR. Em cada fase de anelamento, o fluoróforo se intercala na dupla fita, liberando a fluorescência que é proporcional ao número de cópias. A validação do resultado passa por um processo chamado curva de dissociação: o produto do PCR é aquecido de $60^{\circ}$ até $90^{\circ} \mathrm{C}$, o que leva à separação da dupla fita, com consequente diminuição da fluorescência. Com a curva de dissociação, é possível determinar a especificidade da amplificação (Figura 7). 
Figura 7 - Curvas de dissociação obtidas através de nossos experimentos evidenciando a amplificação de produtos inespecíficos e produto único amplificado
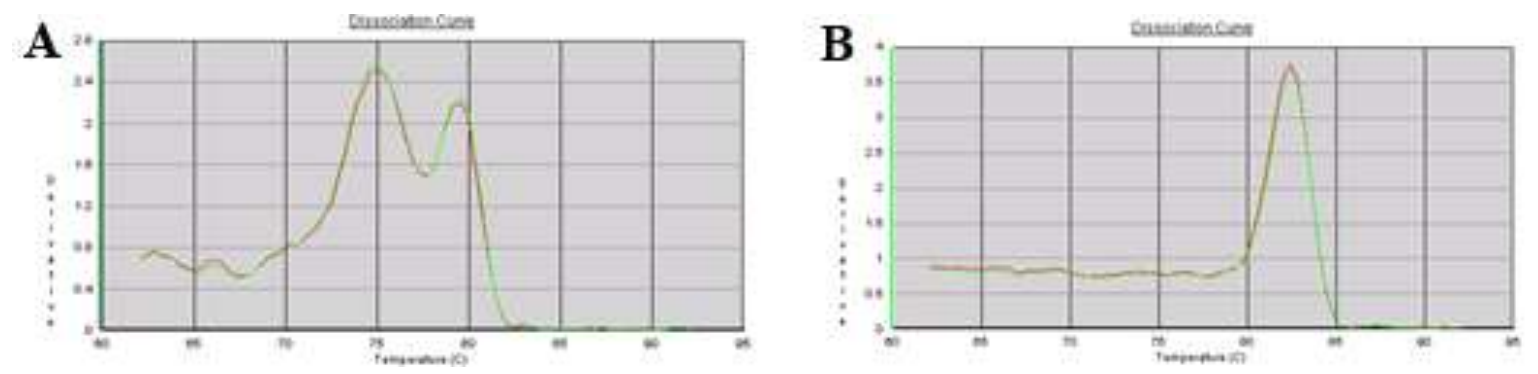

A ordenada corresponde à derivada da fluorescência detectada, e a abscissa à temperatura. (A) Os picos em duas temperaturas indicam que, pelo menos, dois produtos foram gerados na amplificação do PCR; em (B), o pico único indica a produção de apenas um produto, que coincide com o Tm teórico do amplicon esperado.

FONTE: Higa (2012)

Os primers utilizados para averiguação da alteração da expressão dos genes estudados na retina foram transcritos no quadro abaixo, com a respectiva sequência de nucleotídeos utilizada. 
Figura 8 - Sequência de nucleotídeos dos primers utilizados para análise da expressão gênica, através da técnica de PCR-Real time.

\begin{tabular}{|c|c|}
\hline $\begin{array}{c}\text { Gene } \\
\text { (Código GenBank) }\end{array}$ & $\begin{array}{l}\text { Sequência dos Primers } \\
\qquad\left(5^{\prime} \text { a } 3^{\prime}\right)\end{array}$ \\
\hline $\begin{array}{c}\text { Cx } 43 \\
(\mathrm{AY} 324140)\end{array}$ & $\begin{array}{l}\text { FW: TTCCTCGTGCCGCAATTAC } \\
\text { RV: CGATTTTGCTCTGCGCTGTA }\end{array}$ \\
\hline $\begin{array}{c}\text { Cx } 36 \\
\text { (NM_019281) }\end{array}$ & $\begin{array}{l}\text { FW: CTGCAGCCCGGCTGTAA } \\
\text { RV: AGTAACGTATATGGGAGATGGGAAA }\end{array}$ \\
\hline $\begin{array}{c}\text { Ciclina B1 } \\
\text { (NM_171991.2) }\end{array}$ & $\begin{array}{l}\text { FW: AGGACGTGAAGGATGGGAAGT } \\
\text { RV: CCTCACGCAGCTTGTTGTCTAG }\end{array}$ \\
\hline $\begin{array}{c}\text { Ciclina D1 } \\
\text { (NM_171992.4) }\end{array}$ & $\begin{array}{l}\text { FW: TGGGTCTGTGCATTTCTGGTT } \\
\text { RV: CGGCGCTTCCCAGCACCAA }\end{array}$ \\
\hline $\begin{array}{c}18 \mathrm{~s} \\
\text { (NR_046237.1) }\end{array}$ & $\begin{array}{l}\text { FW:AGGACGTGAAGGATGGGAAGT } \\
\text { RV:CCTCACGCAGCTTGTTGTCTAG }\end{array}$ \\
\hline
\end{tabular}

FONTE: Higa (2012)

\subsection{CARACTERIZAÇÃO DO PADRÃO DE EXPRESSÃO PROTEICA POR IMUNO- HISTOQUÍMICA}

Os olhos expostos aos diferentes tempos de lesão foram pós-fixados em paraformaldeído (PFA) 1-4\% diluído em tampão fosfato $0,1 \mathrm{M}$, pH 7,4 (PB) por 30-60 minutos, e crioprotegidos em sacarose $30 \%$ em PB por 30-60 minutos. Secções transversais $(12 \mu \mathrm{m})$ da retina foram obtidas em criostato, e colhidas diretamente em lâminas de vidro gelatinizadas. Os anticorpos primários foram diluídos em 0,5\% Triton X-100 em PB, e a incubação foi realizada por um período de 12-24 horas, à temperatura ambiente. Após este procedimento, os cortes foram incubados com anticorpos secundários conjugados com Alexa488, tetrametil isotiocianato de rodamina (TRITC), ou Cy5 (TRITC, Maine, USA Jackson Labs.), contra as IgGs das espécies onde os anticorpos primários foram produzidos, diluídos 1:100 -1:500 em PB com Triton X-100 por 1-2 horas, em temperatura ambiente. As lâminas expostas à reação foram cobertas com meio de montagem (glicerol carbonato) e lamínulas, seguido de uma fina 
camada de esmalte nas bordas para vedação. O material foi analisado em microscopia confocal. Os anticorpos utilizados para a caracterização dos níveis proteicos das Cxs foram testados em retinas de camundongos $\mathrm{C} \times 36^{-/-}$e $\mathrm{C} \times 43^{+/-}$, doados pelo Dr. Renato Rozental (Albert Einstein College of Medicine), e pela Dra. Maria Lucia Zaidan Dagli (FMVZ-USP), respectivamente. Verificou-se a especificidade do anti-Cx36, pois a marcação não foi observada em retinas de animais knock-out para este gene (Kihara et al., 2006). Pelo fato de animais knock-out para a Cx43 morrerem no primeiro dia após o nascimento, foram utilizadas retinas de animais heterozigotos. A marcação observada foi muito reduzida nas retinas destes camundongos, sugerindo a especificidade do anticorpo utilizado (Kihara et al., 2006).

\subsection{CARACTERIZAÇÃO MORFOLÓGICA DA RETINA EM DIFERENTES TEMPOS PÓS-LESÃO}

Para a avaliação das alterações histológicas das camadas celulares e plexiformes da retina madura, após diferentes intervalos pós-lesão, foram utilizados marcadores nucleares com afinidade por ácidos nucléicos, como o iodeto de propídio (PI), e o 4',6-diamidino-2-phenylindole, dihydrochloride (DAPI). Utilizamos também o marcador glial GFAP (proteína fibrilar glial) para caracterizar a gliose reativa decorrente da lesão. Para aplicação dessas metodologias, os animais foram decapitados, seus olhos retirados e rapidamente colocados em PFA1-4\% em tampão fosfato $0,1 \mathrm{M}, \mathrm{pH} 7,4$ (PB) por 30-60 minutos, e crioprotegidos em sacarose 30\% em PB por 30-60 minutos. Secções transversais $(12 \mu \mathrm{m})$ da retina foram obtidas em criostato, e colhidas diretamente em lâminas de vidro gelatinizadas.

\subsection{CARACTERIZAÇÃO DE MORTE CELULAR PROGRAMADA POR TUNEL}

A degradação do DNA é um dos eventos característicos da apoptose, ocorrendo em seus estágios finais. A identificação desse evento auxilia na identificação e detecção de células que possuam fenótipo apoptótico. A técnica de TUNEL (terminal deoxynucleotidyl transferase-mediated d-UTP nick end-labeling) consiste na identificação de DNA fragmentado, através da incorporação específica de indicadores nos terminais dos nucleotídeos expostos pela fragmentação. 
Para realização dessa técnica, as lâminas contendo cortes de olhos lesados fixados em PFA 4\% foram lavadas duas vezes, durante 10 minutos, em PB 0,05 M (pH $7,4)$. Após a lavagem, as lâminas foram incubadas por 2 minutos $\left(4^{\circ} \mathrm{C}\right)$ em solução permeabilizante, composta de $0,1 \%$ de Triton X-100 e $0,1 \%$ de citrato de sódio em PB $0,05 \mathrm{M}$. Após este procedimento, as lâminas foram lavadas duas vezes, durante 5 minutos $\left(15-25^{\circ} \mathrm{C}\right)$ em PB $0,1 \mathrm{M}$ e incubadas por 60 minutos $\left(37^{\circ} \mathrm{C}\right)$. Para expor 0 DNA, as lâminas são incubadas em uma solução contendo $20 \mu \mathrm{l}$ por proteinase $\mathrm{K}$ por $\mathrm{mL}$ de solução final (PB $0,1 \mathrm{M})$, por 10 minutos $\left(37^{\circ} \mathrm{C}\right)$. Para o alongamento dos fragmentos de DNA os cortes foram incubados em uma solução contendo a enzima TdT, e os nucleotídeos marcados com fluoresceína na proporção de 1:5, provenientes do kit TUNEL (In Situ Cell Death Detection Kit, POD Roche Molecular Biochemicals). Para realização do controle negativo, foi omitido a incubação com a enzima (TdT). Depois de lavadas duas vezes, durante 5 minutos, em PB $0,1 \mathrm{M}$, as lâminas expostas à reação foram cobertas com meio de montagem (glicerol carbonato) e lamínulas, seguido de uma fina camada de esmalte nas bordas para vedação.

\subsection{CARACTERIZAÇÃO DE MORTE CELULAR POR FLUORO-JADE B}

Os experimentos utilizando Fluoro-Jade B foram realizados para averiguação das intensidades de marcação provida pela indução da lesão. Para realização desta técnica, as lâminas contendo cortes de olhos lesados fixados em PFA 4\% foram submetidas a uma série de incubações. Primeiramente, as lâminas foram incubadas em etanol $100 \%$, durante 3 minutos e, posteriormente, em etanol $70 \%$, durante 1 minuto. As lâminas foram posteriormente lavadas em água deionizada, durante 2 minutos. Após este procedimento, as lâminas foram incubadas em permanganato de potássio $0,06 \%$, durante 15 minutos, seguido de lavagem em água deionizada, de 1 minuto. As lâminas foram incubadas novamente, durante 30 minutos, em uma solução contendo $0,001 \%$ do reagente Fluorojade e $0,1 \%$ de ácido acético, seguido de três lavagens de 1 minuto. Após secarem em temperatura ambiente, as lâminas foram submetidas a três

incubações em xilol, durante 2 minutos. Após o término do processo de incubação, as lâminas foram cobertas com meio de montagem (glicerol) e lamínulas, seguido de uma fina camada de esmalte nas bordas para fixação. O material final foi analisado em 
microscopia de fluorescência, contendo o filtro necessário para a florescência adequada do material.

\subsection{QUANTIFICAÇÃO DA EXPRESSÃO PROTEICA POR WESTERN BLOT}

Para avaliação da modulação da expressão das proteínas estudadas, em diferentes tempos pós-lesão, a técnica de lesão foi executada em apenas um dos olhos dos roedores, utilizando o olho contralateral do animal como controle. Foram utilizados de oito a 12 animais para formação dos diferentes grupos, determinados pelo tempo de exposição à lesão, e seus respectivos controles. As retinas tratadas foram coletadas e homogeneizadas em tampão de extração (Tris pH 7,4 100 mM; EDTA 10 mM; PMSF 2 $\mathrm{mM}$ e aprotinina $0,01 \mathrm{mg} / \mathrm{mL}$ ) com auxílio de um sonicador. O material homogeneizado foi centrifugado por 30 minutos a $12.000 \mathrm{rpm}$, a $4^{\circ} \mathrm{C}$. O sobrenadante foi separado do pellet e reservado. Parte do sobrenadante de cada amostra foi diluído a 1:20 em água destilada. Após a quantificação e dosagem da proteína total das amostras realizadas pelo método de Bradford, o material foi aplicado em gel de poliacrilamida e submetido à eletroforese em cuba para mini-gel. As proteínas foram separadas por eletroforese e, em seguida, transferidas para membrana de nitrocelulose $(0,45 \mu \mathrm{m}$ de diâmetro) utilizando um sistema de transferência (Trans-Blot cell system) em tampão contendo SDS. Após a transferência, as membranas foram incubadas em solução de bloqueio contendo $5 \%$ de leite desnatado em salina tamponada, com Tween 20 (TTBS; 0,01 M de Tris- $\mathrm{HCl} ; \mathrm{pH} 7,4 ; 0,15 \mathrm{M}$ de $\mathrm{NaCl} ; 0,05 \%$ de Tween 20) durante duas horas, sob agitação leve. As membranas foram então lavadas e incubadas com diferentes tipos de anticorpos primários, contra as diferentes proteínas de estudos por $12-14$ horas $\left(4^{\circ} \mathrm{C}\right)$, em PBS contendo leite 5\%. Após lavagens em TTBS ( $\mathrm{NaCl}$ 0,5 M; Tris- $\mathrm{HCl} 50 \mathrm{mM}$; Tween 20 0,1\%), as membranas foram incubadas com anticorpo secundário, marcado com peroxidase em TTBS, contendo leite $1 \%$, por duas horas, a temperatura ambiente. A revelação foi realizada em câmara escura utilizando o kit ECL (1:1, Amersham). 


\subsection{ANÁLISE ESTATÍSTICA}

Dados provenientes de análises quantitativas (por exemplo, PCR, Western Blot) foram submetidos à análise de Test $T$ pareado, com valor de significância menor que $5 \%(p<0,05)$. Análises qualitativas (imunoistoquímica, descrições morfológicas), sempre que possível, foram efetuadas em teste cego, com examinadores isentos. Além disso, resultados foram considerados apenas quando reprodutíveis em, pelo menos, três experimentos independentes. 


\subsection{ANÁLISE DA EXPRESSÃO GÊNICA POR PCR REAL-TIME}

Os primers utilizados para obtenção dos resultados de PCR Real-Time foram validados através de uma curva-padrão, realizada a partir de uma série de diluições de cDNA e seus respectivos slopes (eficiência $=10^{(-1 / \text { slope) }}-1$ ). Foram considerados como viáveis os primers que apresentaram eficiência entre $90 \%$ e $110 \%$, de modo que as curvas de dissociação resultantes desta análise (controle de amplificações inespecíficas) apresentassem um pico único, indicando a amplificação de um único produto de PCR resultante em cada reação, portanto especificidade da amplificação do gene alvo.

As amostras utilizadas para análise da expressão gênica foram submetidas a teste de variação do gene respectivo a proteína 18S (gene utilizado como controle interno do experimento de PCR). As análises indicaram ausência de alterações do gene em questão. Os dados representados indicam os valores obtidos por meio da diferença entre os valores das amostras controle e lesão, referentes a cada período de exposição à lesão.

\subsubsection{Expressão gênica das Cxs 36 e 43 em diferentes tempos pós-lesão}

Os resultados de PCR em tempo real revelaram ausência de modulação da expressão gênica da Cx36 nos diferentes tempos pós-lesão analisados. Entretanto, nossos resultados mostraram um aumento dos transcritos de Cx43, após três e sete dias de lesão. Nos demais períodos avaliados (duas e seis horas) não foram detectados variações significativas da expressão gênica de Cx43 na retina em função da lesão (Figura 9). 
Figura 9 - Expressão gênica das Cx36 e Cx43 após lesão mecânica na retina de ratos

A

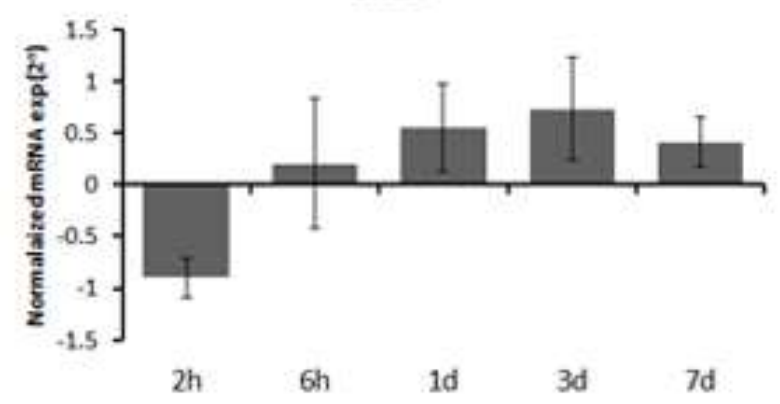

B

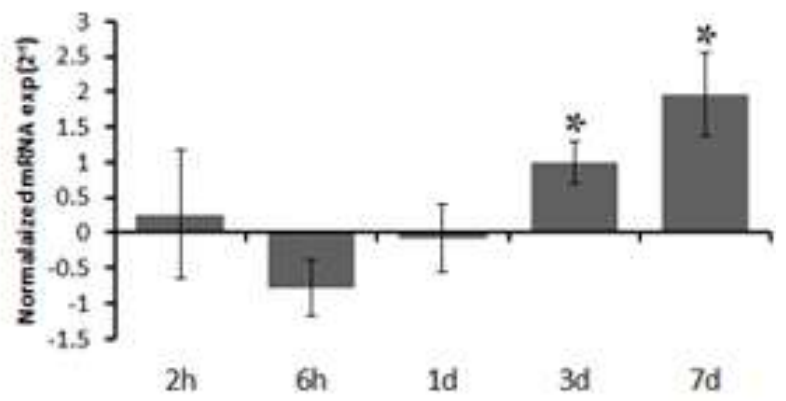

$\mathrm{Na}$ ordenada estão representados os valores de expressão gênica encontrados na retina lesada, normalizados pela respectiva retina controle (2n). Neste sistema de representação, 1 equivale ao dobro da expressão, e o valor -1 equivale à $50 \%$. As barras representam as médias com o respectivo erro padrão. (A) Nossos resultados de PCR em tempo real indicaram ausência de modulação da Cx36. (B) As análises sobre os níveis dos transcritos da $\mathrm{Cx} 43$ demonstraram aumento dos transcritos de $\mathrm{Cx} 43$, após três e sete dias de lesão. Para avaliação da variação da expressão dos genes estudados em diferentes tempos pós-lesão, a técnica de lesão foi executada em apenas um dos olhos dos roedores, utilizando o olho contralateral do animal como controle. $n=4-6$. ${ }^{*} P<0,05$, vs. respectivo controle, teste $T$ pareado.

FONTE: Higa (2012)

\subsubsection{Expressão gênica das ciclinas D1 e B1 em diferentes tempos pós-lesão}

Os resultados de PCR em tempo real demonstraram uma variação na expressão gênica da ciclina D1 e B1, em um, três e sete dias pós-lesão. Ambas ciclinas apresentaram uma maior modulação após três dias de lesão. Nos demais períodos avaliados (duas e seis horas), não foram detectadas variações significativas da expressão gênica das ciclinas analisadas (Figura 10). 
Figura 10 - Expressão gênica das ciclina D1 e B1 após lesão mecânica na retina de ratos

A

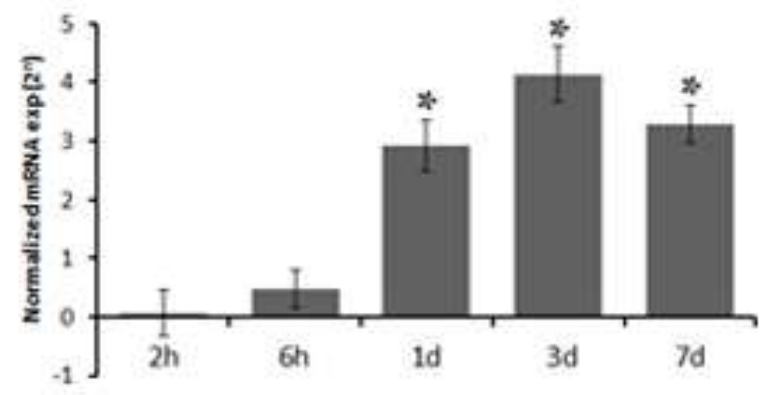

B

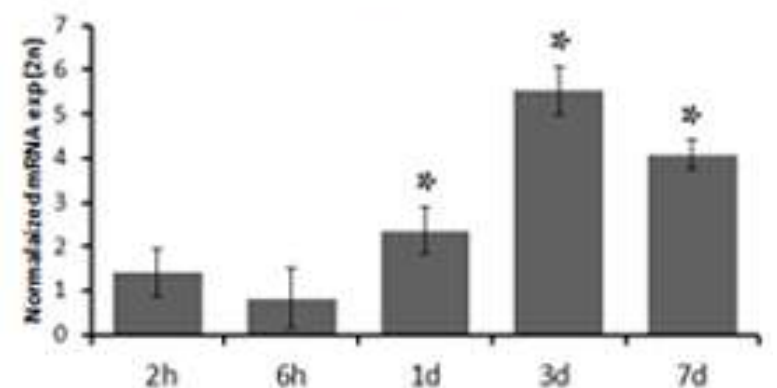

$\mathrm{Na}$ ordenada estão representados os valores de expressão gênica encontrados na retina lesada, normalizados pela respectiva retina controle (2n). Neste sistema de representação, 1 equivale ao dobro da expressão, e o valor -1 equivale à $50 \%$. As barras representam as médias com o respectivo erro padrão. (A) Os resultados de PCR em tempo real indicaram um aumento dos transcritos de ciclina D1 após um, três e sete dias de lesão. Nos demais períodos avaliados (duas e seis horas) não foram detectadas variações significativas da expressão deste gene na retina. (B) As análises indicaram aumento dos transcritos de ciclina B1, após um, três e sete dias de lesão. Para avaliação da variação da expressão dos genes estudados em diferentes tempos pós-lesão, a técnica de lesão foi executada em apenas um dos olhos dos roedores, utilizando o olho contralateral do animal como controle. $n=4-6$. ${ }^{*} P<$ 0,05 , vs. respectivo controle, teste T pareado.

FONTE: Higa (2012)

\subsection{ANÁLISES DOS NÍVEIS PROTEICOS POR WESTERN BLOT.}

Análises dos níveis proteicos das diferentes proteínas estudadas foram realizadas através da técnica de Western Blot, sendo utilizada a proteína beta-actina como controle interno. Os dados obtidos estão representados pelos valores da densidade óptica da proteína estudada, normalizada através da razão do valor da densidade óptica das bandas obtidas pelo controle interno.

\subsubsection{Análises dos níveis proteicos das Cxs em diferentes tempos de exposição à lesão mecânica na retina.}

As análises dos níveis proteicos totais das retinas submetidas à lesão pontual da retina, quando comparadas com seus respectivos controles, não apresentaram alterações significativas paras as diferentes conexinas analisadas (Figura 11 e 12) e para ciclina D1 (Figura 13). 
Figura 11 - Níveis proteicos da Cx36 na retina

A

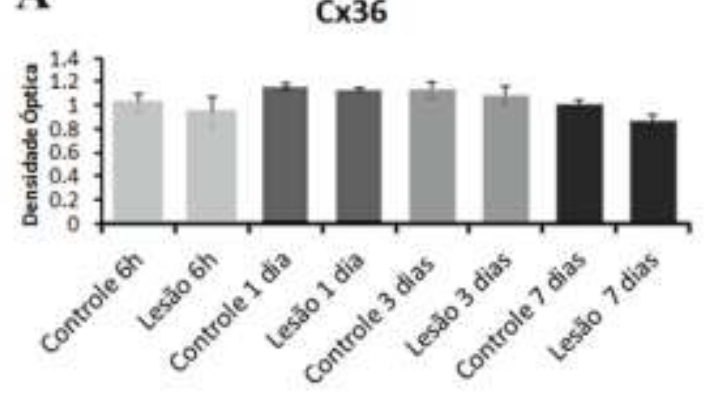

B

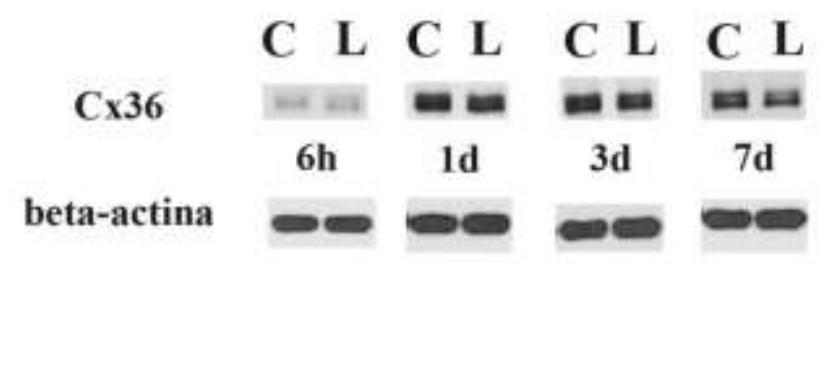

Ausência de modulação dos níveis proteicos da Cx36, após lesão mecânica na retina de ratos (A). Bandas representativas dos níveis proteicos da Cx36 com seu respectivo controle interno (B) $\mathrm{Na}$ ordenada estão representados os valores normalizados pela média da densidade óptica do controle interno. As barras representam a as médias de cada amostra, com o respectivo erro padrão. Os resultados de Western Blot indicaram ausência de modulação da Cx36 (A e B, respectivamente) para os diferentes tempos de exposição à lesão. $n=4-6$. ${ }^{*} P<0,05$, vs. respectivo controle, teste $T$ pareado.

FONTE: Higa (2012)

Figura 12 - Níveis proteicos da Cx43 na retina A Cx43 B

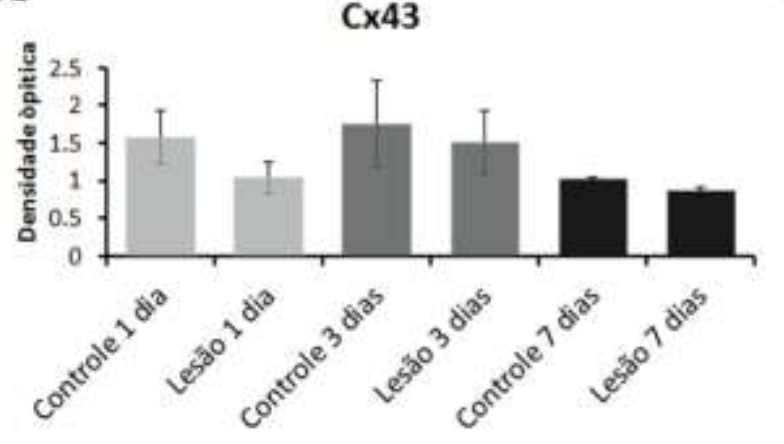

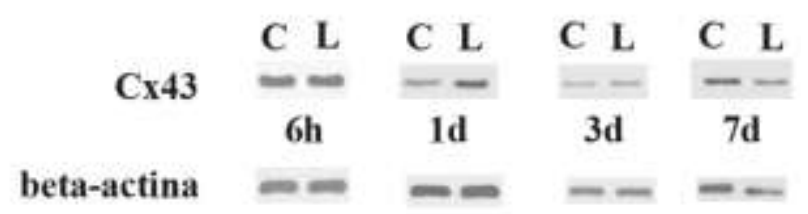

Ausência de modulação dos níveis proteicos da Cx43, após lesão mecânica na retina de ratos (A). Bandas representativas dos níveis proteicos da Cx43 com seu respectivo controle interno (B). $\mathrm{Na}$ ordenada estão representados os valores normalizados pela média da densidade óptica do controle interno. As barras representam a as médias de cada amostra, com o respectivo erro padrão. Os resultados de Western Blot indicaram ausência de modulação da Cx43 (A e B, respectivamente) para os diferentes tempos de exposição à lesão. $n=4-5$. ${ }^{*} \mathrm{P}<0,05$, vs. respectivo controle, teste $\mathrm{T}$ pareado.

FONTE: Higa (2012) 
Figura 13 - Níveis proteicos da ciclina D1 na retina

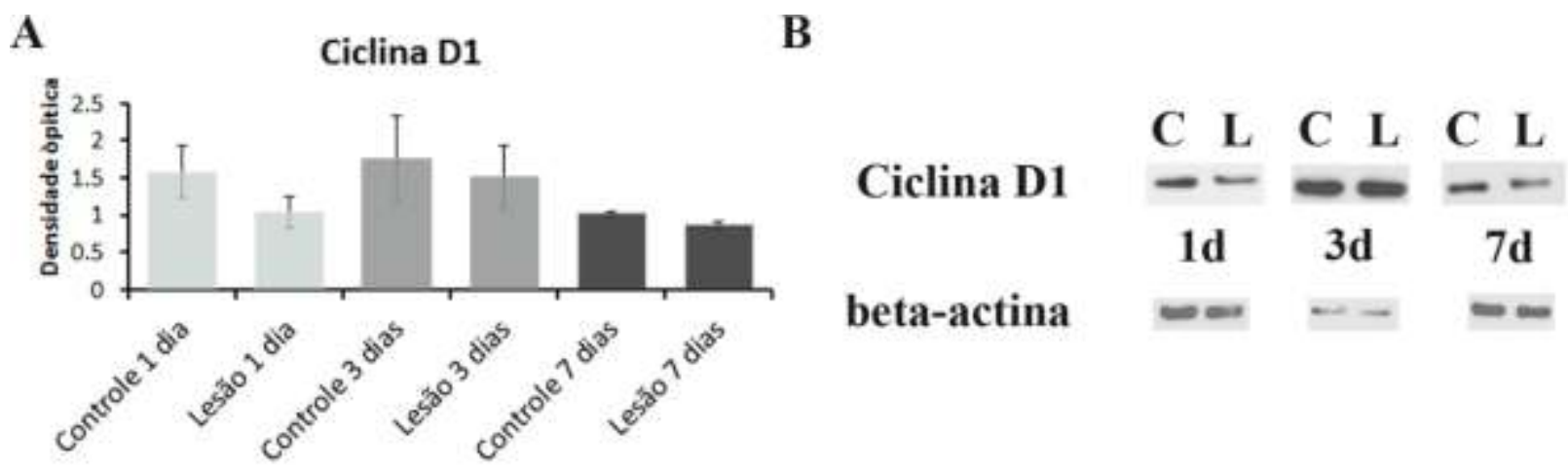

Ausência de modulação dos níveis proteicos da ciclina D1, após lesão mecânica na retina de ratos (A). Bandas representativas dos níveis proteicos da Ciclina D1 com seu respectivo controle interno (B). Na ordenada estão representados os valores normalizados pela média da densidade óptica do controle interno. As barras representam a as médias de cada amostra, com o respectivo erro padrão. Os resultados de Western Blot indicaram ausência de modulação da ciclina D1 (A e B, respectivamente) para os diferentes tempos de exposição à lesão. $n=4-5$. ${ }^{*} \mathrm{P}<0,05$, vs. respectivo controle, teste $\mathrm{T}$ pareado.

FONTE: Higa (2012)

\subsection{AVALIAÇÃO DA MODULAÇÃO PROTEICA POR AVALIAÇÃO TECIDUAL.}

Os resultados histológicos obtidos através da utilização de técnicas de imunofluorescência foram viabilizados depois de realizada analises sobre a omissão do controle primário (controle negativo), sendo considerado viáveis os padrões de marcação distintos desse experimento deste procedimento e compatíveis com marcações presentes na literatura.

\subsubsection{A regulação da expressão proteica de Cxs é diferenciada durante o processo degenerativo}

A regulação espaço-temporal de Cxs pelo processo neurodegenerativo é particular para cada Cx. Aparentemente a marcação da Cx36 apresenta uma redistribuição diferenciada para cada período pós-lesão. Após um dia de lesão, os níveis proteicos da C×36 aparentemente diminuem no foco da lesão, com aumento observável em sua zona de penumbra. Após três dias de lesão, as retinas tipicamente apresentaram diminuição de marcação para Cx36 no foco da lesão, com variações não representativas em sua zona de penumbra. O padrão de marcação da Cx36 observado 
em retinas controle é alterado com a indução da lesão e sua ação no tempo. É possível observar que a Cx36 apresenta-se difusa em ambas as camadas plexiformes da retina, sendo esse processo melhor evidenciado após sete dias de lesão (Figura 14). 
Figura 14 - Análise da expressão de Cx36 por microscopia confocal no modelo de lesão mecânica
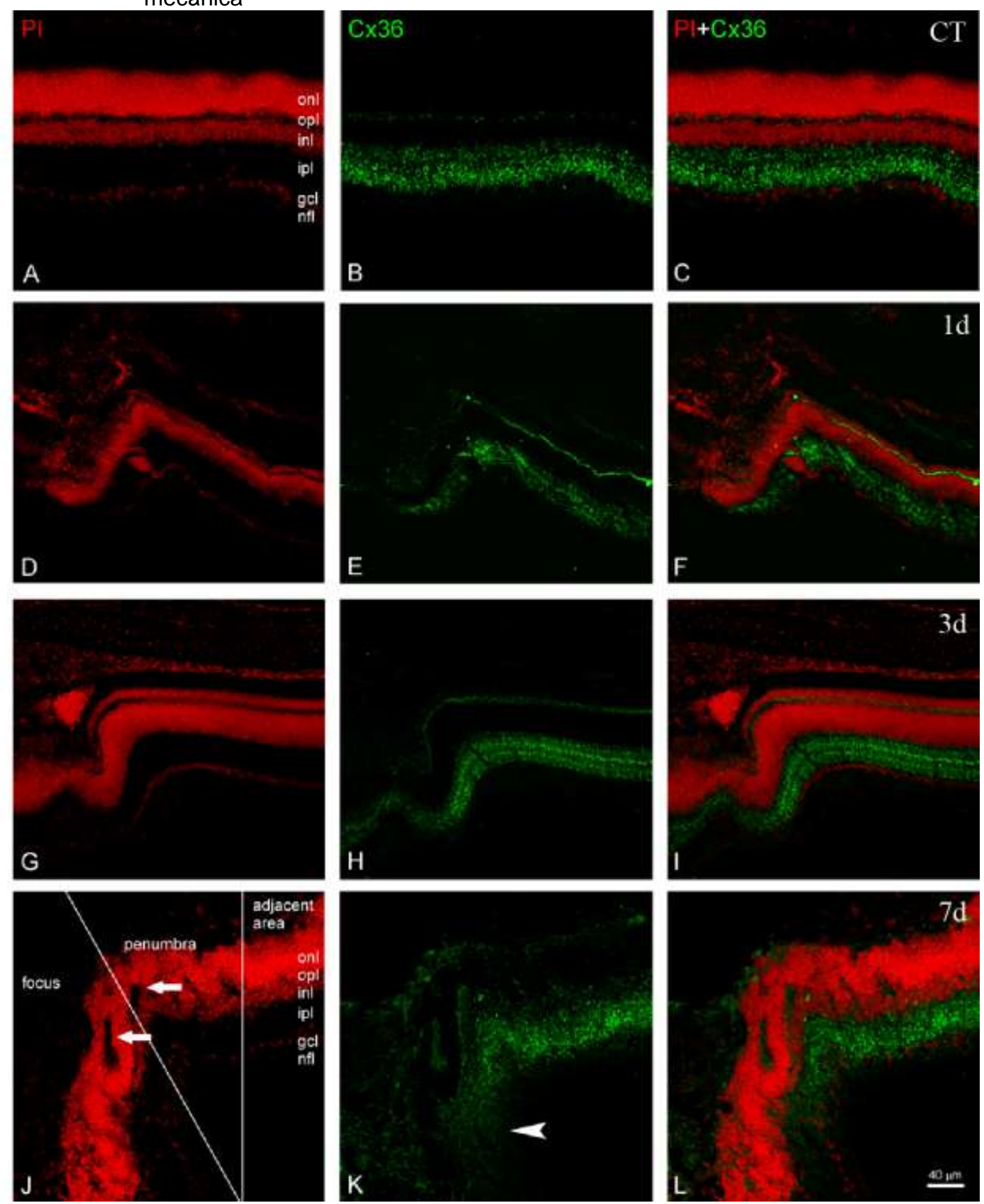
Contra coloração das camadas nucleares da retina por PI em retinas controle (A) e lesada após um dia $(D)$, três dias $(G)$ e sete dias $(J)$. A área central interrompida corresponde ao centro da lesão. Caracterização da expressão de Cx36 em retinas controle $(B)$ e lesada após um dia (E), três dias $(H)$ e sete dias (K). Sobreposição das imagens de retinas controle $(C)$ e lesadas após um dia $(F)$, três dias $(I)$ e sete dias (L). Na retina controle observamos uma marcação puntiforme na IPL, sobretudo na margem interna, e na OPL. ONL, camada nuclear externa; OPL, camada plexiforme externa, INL, camada nuclear interna; IPL, camada plexiforme interna; GCL, camada de células ganglionares; NFL, camada de axônios retinianos. Barra de escala: $40 \mu \mathrm{m}$.

FONTE: Higa (2012) 
A marcação para Cx43 parece sofrer alterações em seu padrão de distribuição. Entretanto, no caso da Cx43, observamos um aparente acúmulo da proteína no foco e imediações da lesão, após todos os períodos de sobrevida analisados (Figura 15). Aparentemente este aumento da marcação é causado tanto pela presença em células do epitélio pigmentado quanto por astrócitos próximos a camada de fibras (nfl) (Figura 16). 
Figura 15 - Análise da expressão de Cx43 por microscopia confocal no modelo de lesão mecânica.
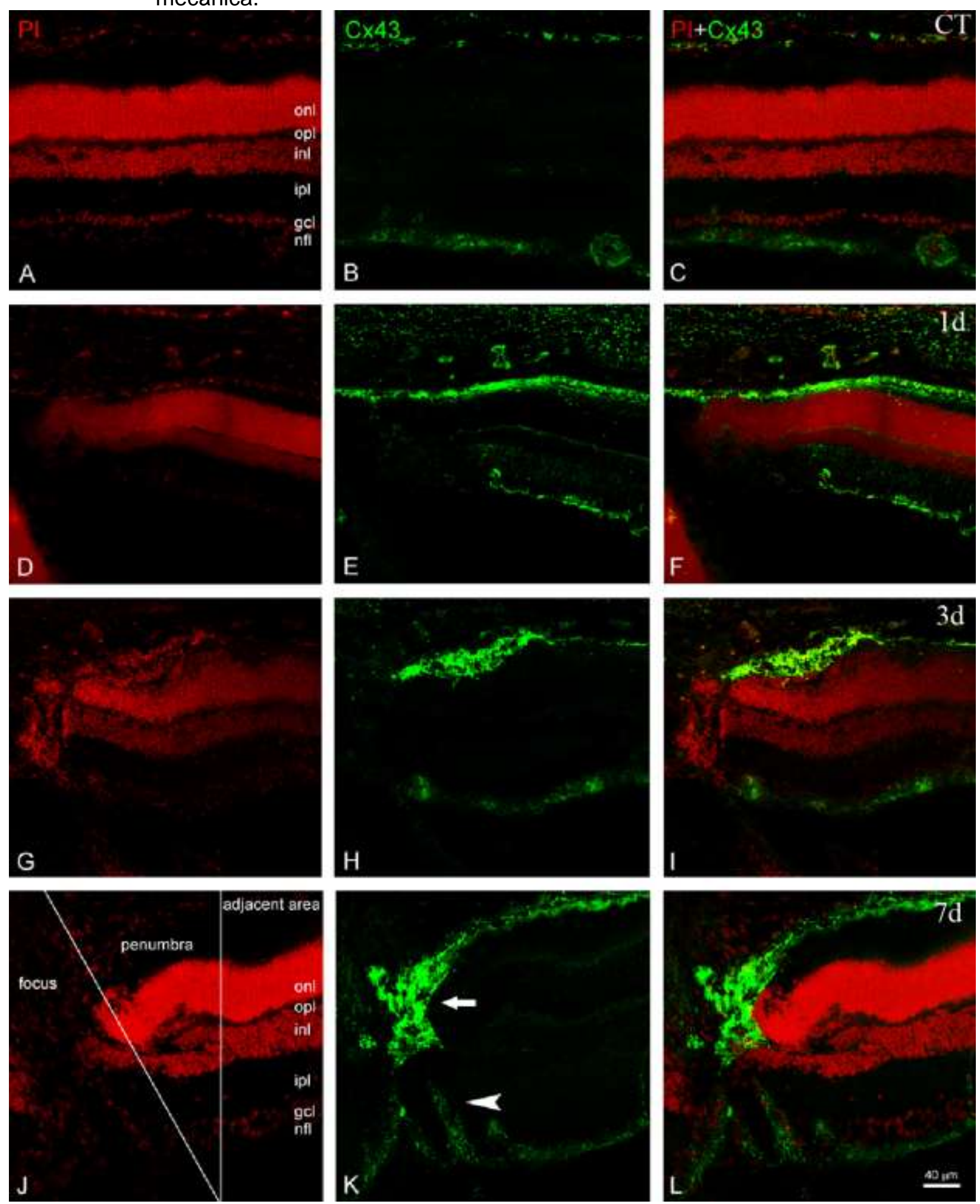
Contra coloração das camadas nucleares da retina por iodeto de propídio (PI) em retinas controle (A) e lesada após 1 dia (D), 3 dias $(G)$ e 7 dias (J). A área central interrompida corresponde ao centro da lesão. Caracterização da expressão de Cx43 em retinas controle (B) e lesada após 1 dia $(E), 3$ dias $(H)$ e 7 dias (K). Sobreposição das imagens de retinas controle (C) e lesadas após 1 dia (F), 3 dias (I) e 7 dias (L). Na retina controle observamos uma marcação puntiforme na camada de fibras (nfl), em localização compatível com a expressão por astrócitos. Além disso, encontramos imuno-reatividade (IR) na margem externa da retina, mais especificamente em células do epitélio pigmentado. Na retina lesada, observamos um aumento da IR ao foco e penumbra da lesão em todos os períodos pós-lesão analisados. Este aumento de marcação aparentemente é causado tanto pela expressão em células do epitélio pigmentado (seta) quanto por astrócitos (cabeça de seta). ONL, camada nuclear externa; OPL, camada plexiforme externa, INL, camada nuclear interna; IPL, camada plexiforme interna; GCL, camada de células ganglionares; NFL, camada de axônios retinianos. Barra de escala: $40 \mu \mathrm{m}$.

FONTE: Higa (2012) 
Figura 16 - Análise da expressão de Cx43 e processos de astrócitos por microscopia confocal no modelo de lesão mecânica
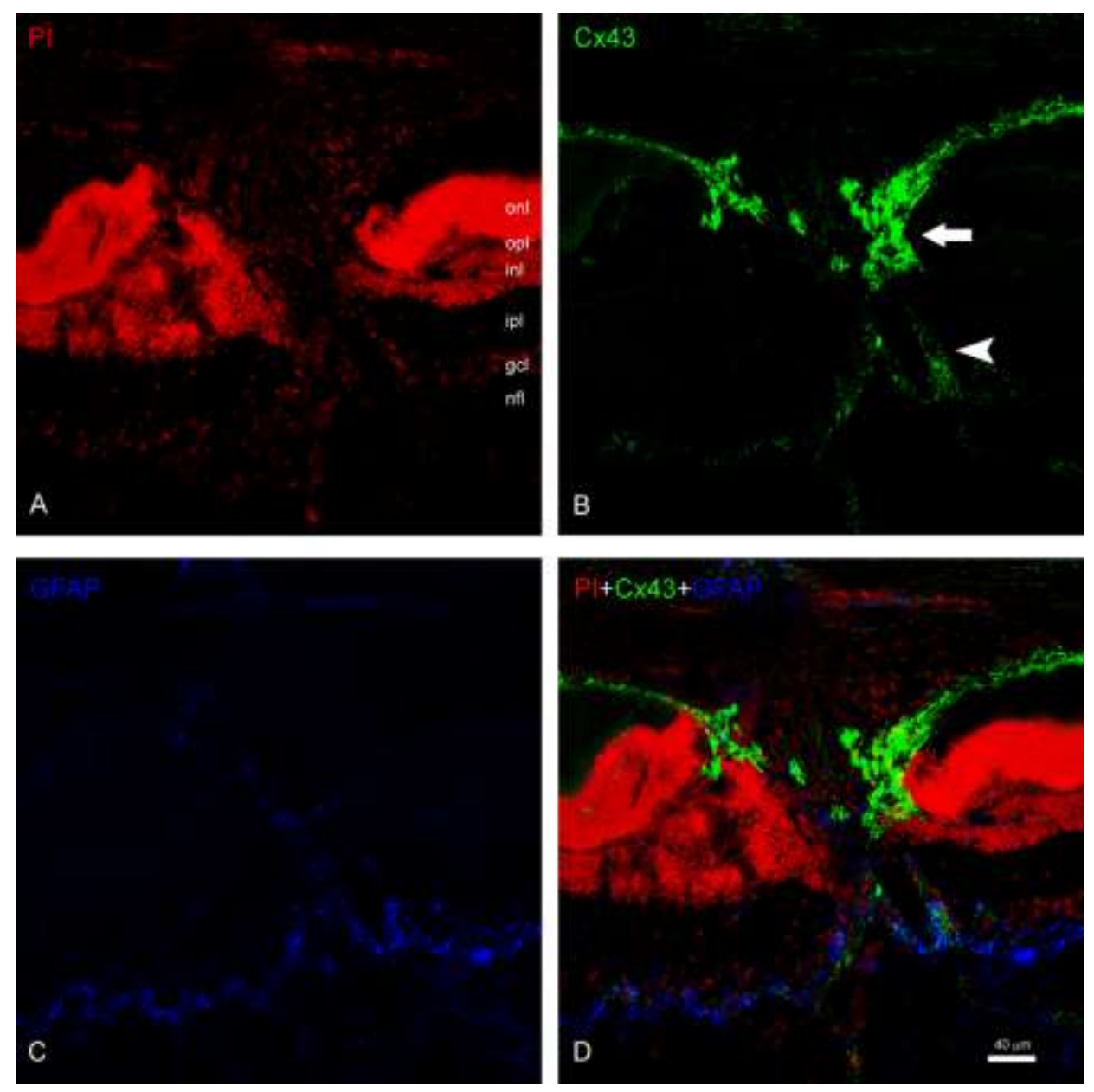

Contra coloração das camadas nucleares da retina por PI em retina após um dia de lesão $(A)$. A área central interrompida corresponde ao centro da lesão. Caracterização da expressão de Cx43 na retina após um dia de lesão (B). Contra coloração dos processos de astrócitos por GFAP na retina após um dia de lesão. Sobreposição das imagens da retina lesada (D). Na retina analisada observamos uma marcação puntiforme na camada de fibras (nfl), apresentando uma colocalização com a marcação dos processos de astrócitos (GFAP). Além disso, encontramos imuno-reatividade (IR) na margem externa da retina, mais especificamente em células do epitélio pigmentado. Esses resultados apontam que 0 aumento da expressão da Cx43 ocorre principalmente nas células do epitélio pigmentado, tanto no foco quanto na zona de penumbra da lesão, com um aumento menos significativo da Cx43 nas células gliais em relação a essas mesmas áreas. Barra de escala: $40 \mu \mathrm{m}$.

FONTE: Higa (2012)

\subsubsection{A regulação dos níveis proteicos da ciclina $D 1$ e $B 1$ é diferenciada durante o processo degenerativo.}

Os níveis de marcação da ciclina D1 apresentaram-se aumentados com a indução da lesão mecânica após um dia e três dias de lesão. Em um dia de lesão os 
níveis de marcação da ciclina D1 se encontram aparentemente aumentados na camada nuclear interna (INL) e na camada de células ganglionares (GCL). A marcação pertinente a ciclina $\mathrm{D} 1$ presente na INL, aparenta ser nuclear devido à colocalização de sua marcação com marcadores de ácidos nucleicos na maior parte das células ciclina D1 positivas. Já o padrão de marcação presente na $\mathrm{GCL}$, próxima à lesão, demonstra não colocalizar, na maior parte das células analisadas, com núcleos celulares presentes nessa camada, além de não ocorrer se encontrar expressa em células macrogliais (Figura 17 e 19). Em retinas expostas a três dias de lesão apresentam o mesmo padrão de marcação em relação às retinas expostas a lesão por 24 horas, porém apresentando menor intensidade em relação à mesma (Figura 18).

Figura 17 - Análise microscópica da Ciclina D1 métodos histoquímicos no modelo de lesão mecânica.
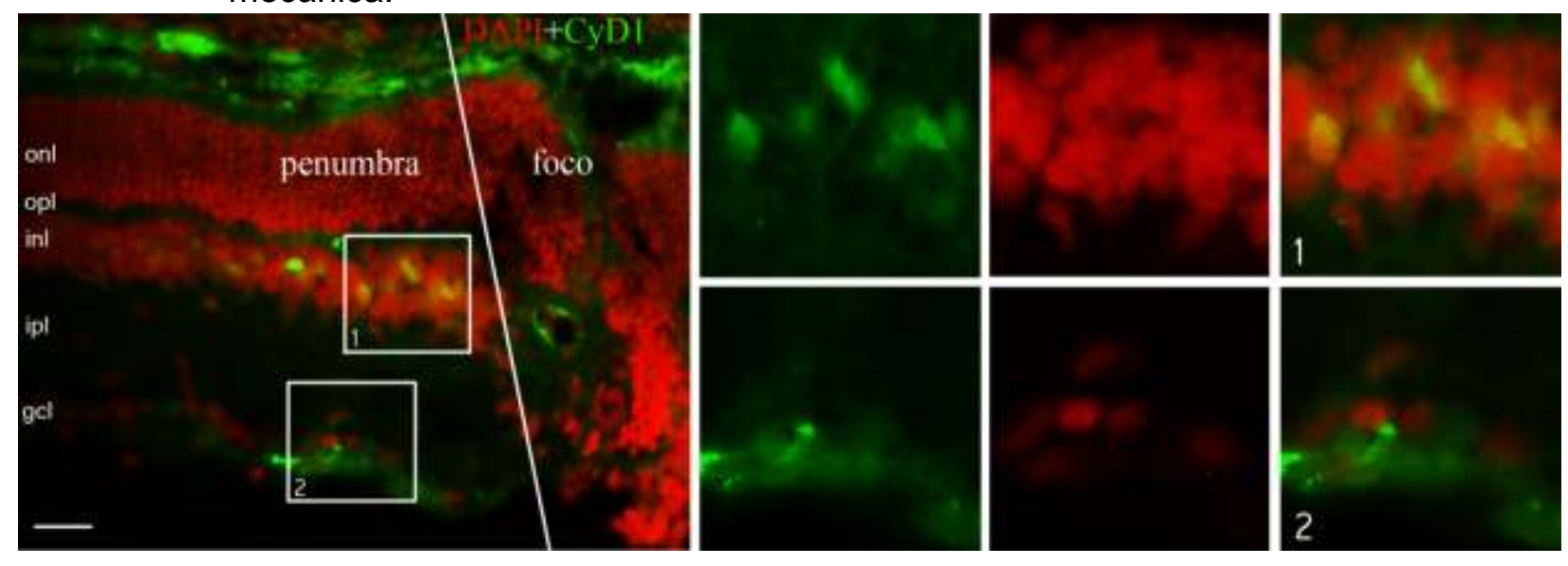

Presença de marcação de ciclina D1 em retinas expostas a um dia de lesão. Imagem sobreposta contendo marcação com DAPI e ciclina D1 (CyD1). As retinas lesadas apresentam aumento da marcação de ciclina D1 na área de penumbra e regiões adjacentes ao foco da lesão. Aparentemente células da camada nuclear interna (INL) apresentam um aumenta dos níveis da ciclina D1 devido à exposição à lesão (1). Células presentes na camada ganglionar apresentam um aumento nos níveis proteicos de ciclina D1 na área de penumbra da lesão (2). ONL, camada nuclear externa; OPL, camada plexiforme externa, INL, camada nuclear interna; IPL, camada plexiforme interna; GCL, camada de células ganglionares. Barra de escala: $25 \mu \mathrm{m}$. 
Figura 18 - Análise dos níveis proteicos de Ciclina D1 por métodos histoquímicos no modelo de lesão mecânica

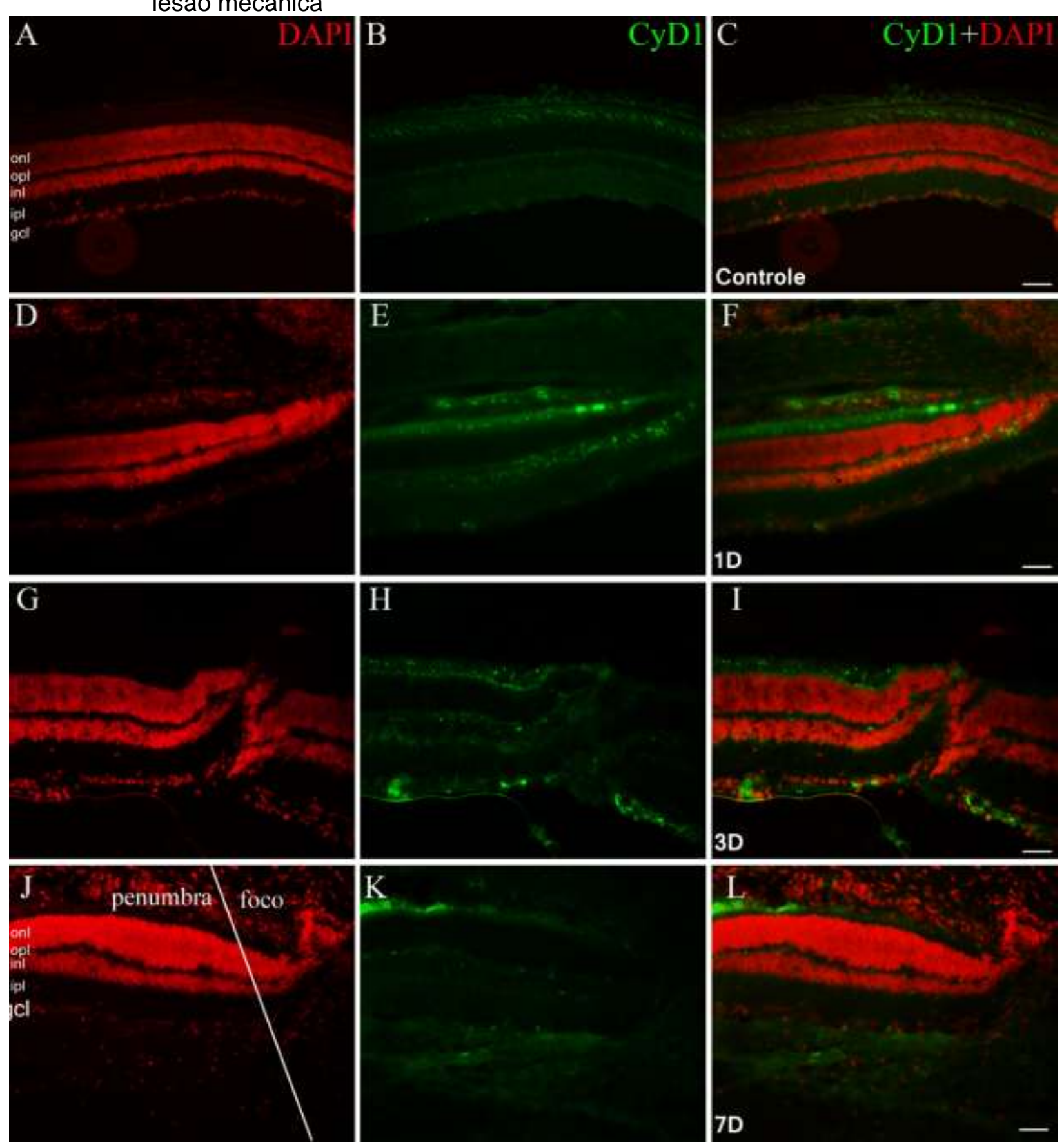

Contra coloração das camadas nucleares da retina DAPI em retina controle (A) e lesada após um dia (D), três $(\mathrm{G})$ e sete dias (J). A área central interrompida corresponde ao centro da lesão. Níveis proteicos da ciclina D1 em retinas controle $(B)$ e lesada após um dia $(E)$, três dias $(H)$ e sete dias $(L)$. Sobreposição das imagens da retina controle $(C)$ e lesada após um $(F)$, três dias $(I)$ e sete dias $(L)$ de lesão. Na retina após um e três dias de lesão, observamos um aumento da marcação da ciclina D1 nas áreas adjacentes ao foco da lesão. ONL, camada nuclear externa; OPL, camada plexiforme externa, INL, camada nuclear interna; IPL, camada plexiforme interna; GCL, camada de células ganglionares. Barra de escala: $50 \mu \mathrm{m}$. FONTE: Higa (2012) 
Figura 19 - Análise da expressão de ciclina D1 e processos de astrócitos por microscopia no modelo de lesão mecânica
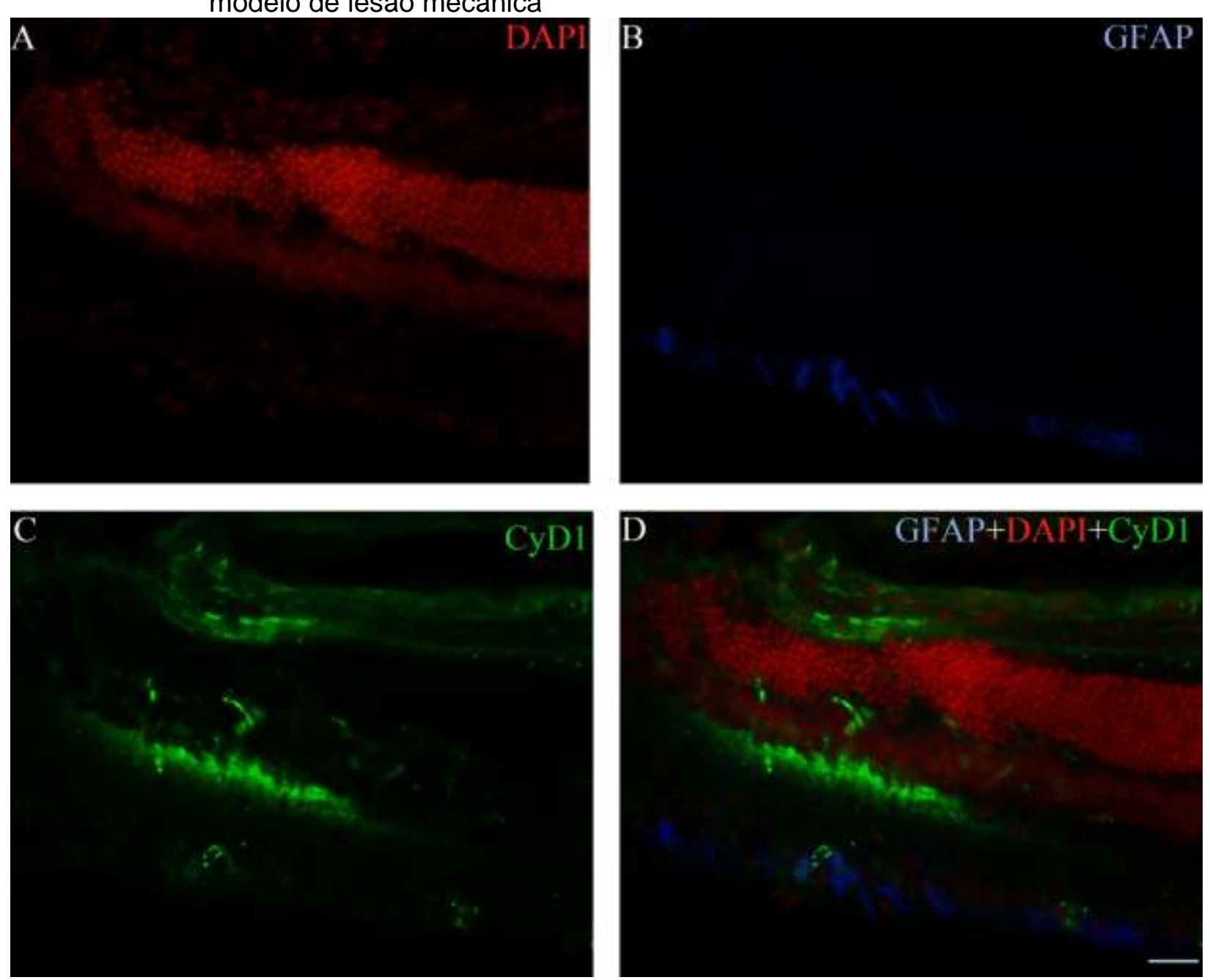

Contra coloração das camadas nucleares da retina por DAPI em retina após um dia de lesão $(A)$. $A$ área interrompida a esquerda corresponde ao centro da lesão. Caracterização da expressão de ciclina D1 na retina após um dia de lesão (B). Contra coloração dos processos de astrócitos por GFAP na retina após um dia de lesão (C). Sobreposição das imagens da retina lesada (D). Na retina analisada observamos a marcação da ciclina D1 na IPL, INL e GCL, havendo ausência de colocalização com o marcador de células da macroglia (GFAP). Além disso, encontramos imuno-reatividade (IR) na margem externa da retina, mais especificamente em células do epitélio pigmentado. Barra de escala: $25 \mu \mathrm{m}$.

FONTE: Higa (2012)

As marcações de ciclina B1, por sua vez, surgem com a indução da lesão mecânica após um dia (Figura 20 e 21). Nesse período a marcação da ciclina B1 está presente no foco da lesão contemplando toda espessura da retina. O padrão de marcação da ciclina B1 no foco da lesão é puntiforme e não colocaliza com marcadores nucleares (Figura 21). 
Figura 20 - Análise dos níveis proteicos de Ciclina B1 por métodos histoquímicos no modelo de lesão mecânica
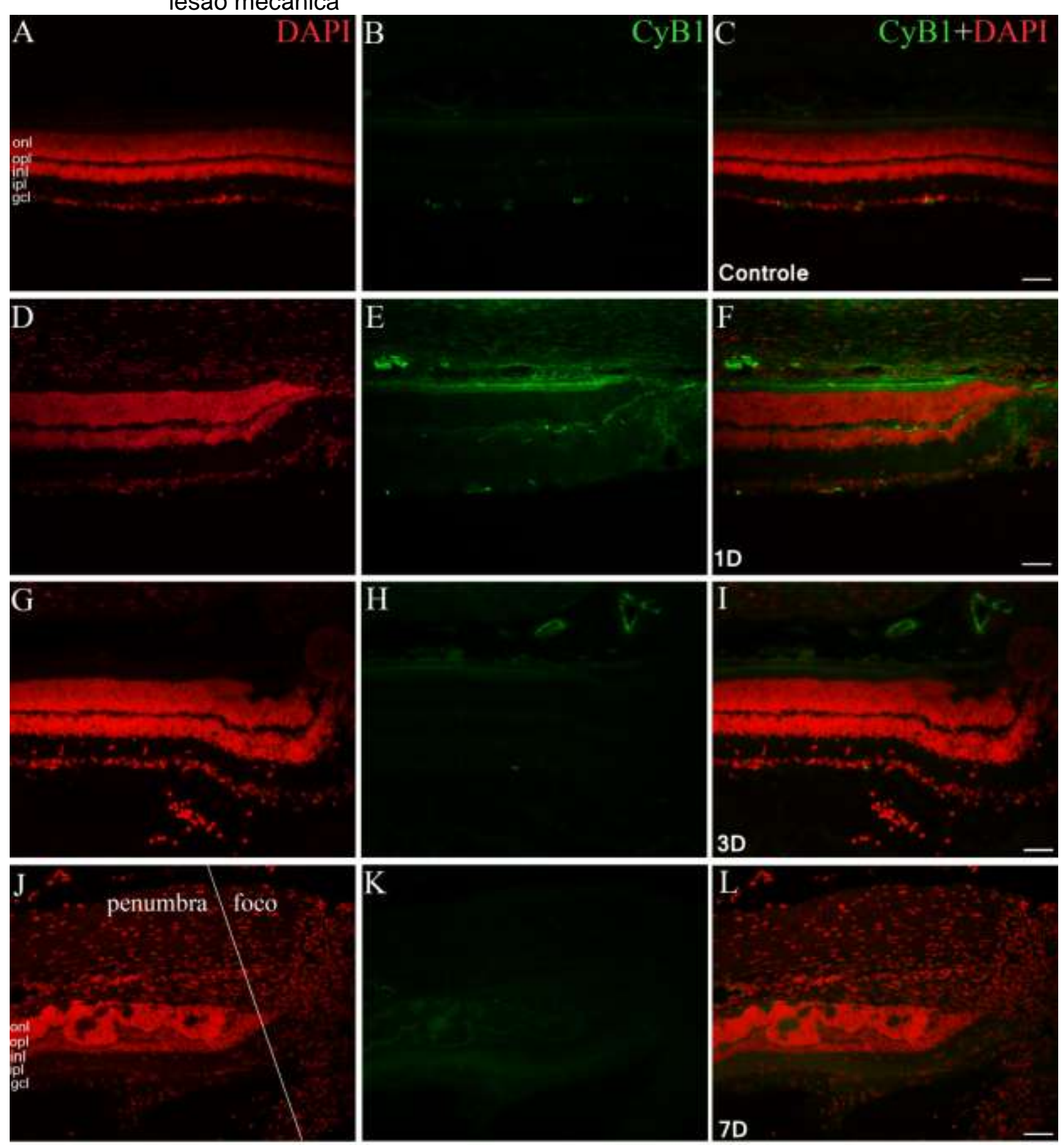

Contra coloração das camadas nucleares da retina DAPI em retina controle (A) e lesada após um dia (D), três $(\mathrm{G})$ e sete dias $(\mathrm{J})$. A área central interrompida corresponde ao centro da lesão. Níveis proteicos da ciclina D1 em retinas controle $(B)$ e lesada após um dia $(E)$, três dias $(H)$ e sete dias $(L)$. Sobreposição das imagens da retina controle $(C)$ e lesada após um (F), três dias (I) e sete dias $(L)$ de lesão. Na retina após um dia de lesão, observamos um aumento da marcação da ciclina B1 na área respectiva ao foco da lesão. ONL, camada nuclear externa; OPL, camada plexiforme externa, INL, camada nuclear interna; IPL, camada plexiforme interna; GCL, camada de células ganglionares. Barra de escala: $50 \mu \mathrm{m}$.

FONTE: Higa (2012) 
Figura 21 - Análise microscópica da Ciclina B1 métodos histoquímicos no modelo de lesão mecânica
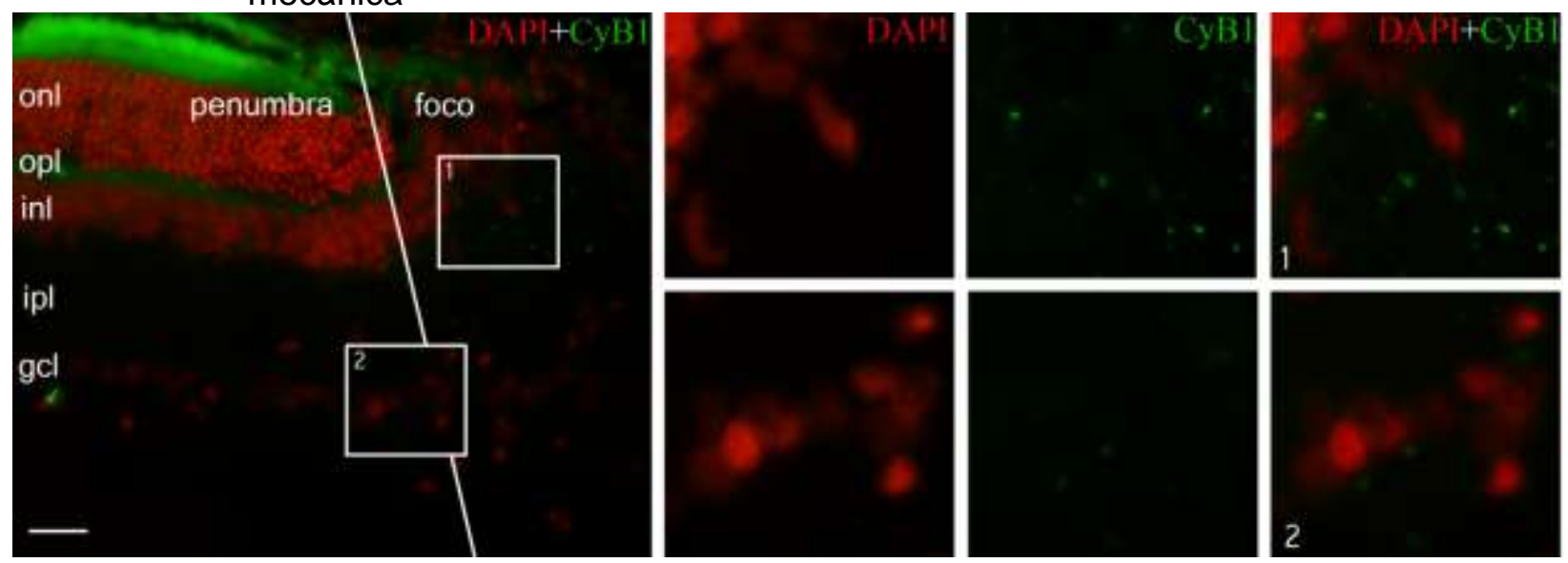

Presença de marcação de ciclina B1 em retinas expostas a um dia de lesão. Imagem sobreposta contendo marcação com DAPI e ciclina B1 (CyB1). As retinas lesadas apresentam marcação de ciclina B1 na área de penumbra no foco da lesão (1) e áreas próximas a ela (2). Aparentemente células da camada nuclear interna (INL) apresentam um aumenta dos níveis da ciclina D1 devido à exposição à lesão (1). Células presentes na camada ganglionar apresentam marcação da ciclina B1 na área de penumbra da lesão (2). ONL, camada nuclear externa; OPL, camada plexiforme externa, INL, camada nuclear interna; IPL, camada plexiforme interna; GCL, camada de células ganglionares. Barra de escala: $25 \mu \mathrm{m}$.

FONTE: Higa (2012)

\subsubsection{Dinâmica da morte celular por necrose no presente modelo de neurodegeneração}

Utilizando o marcador histoquímico Fluoro-Jade B (FJ), caracterizamos a morte celular por necrose em nosso modelo, nos períodos de duas horas, um dia, três dias e sete dias pós-lesão. Nossos resultados indicaram uma marcação por FJ particularmente evidente nos tempos de um e três dias pós-lesão no foco e áreas próximas a ela (Figura 22). 
Figura 22 - Caracterização da morte celular por Fluoro-Jade B
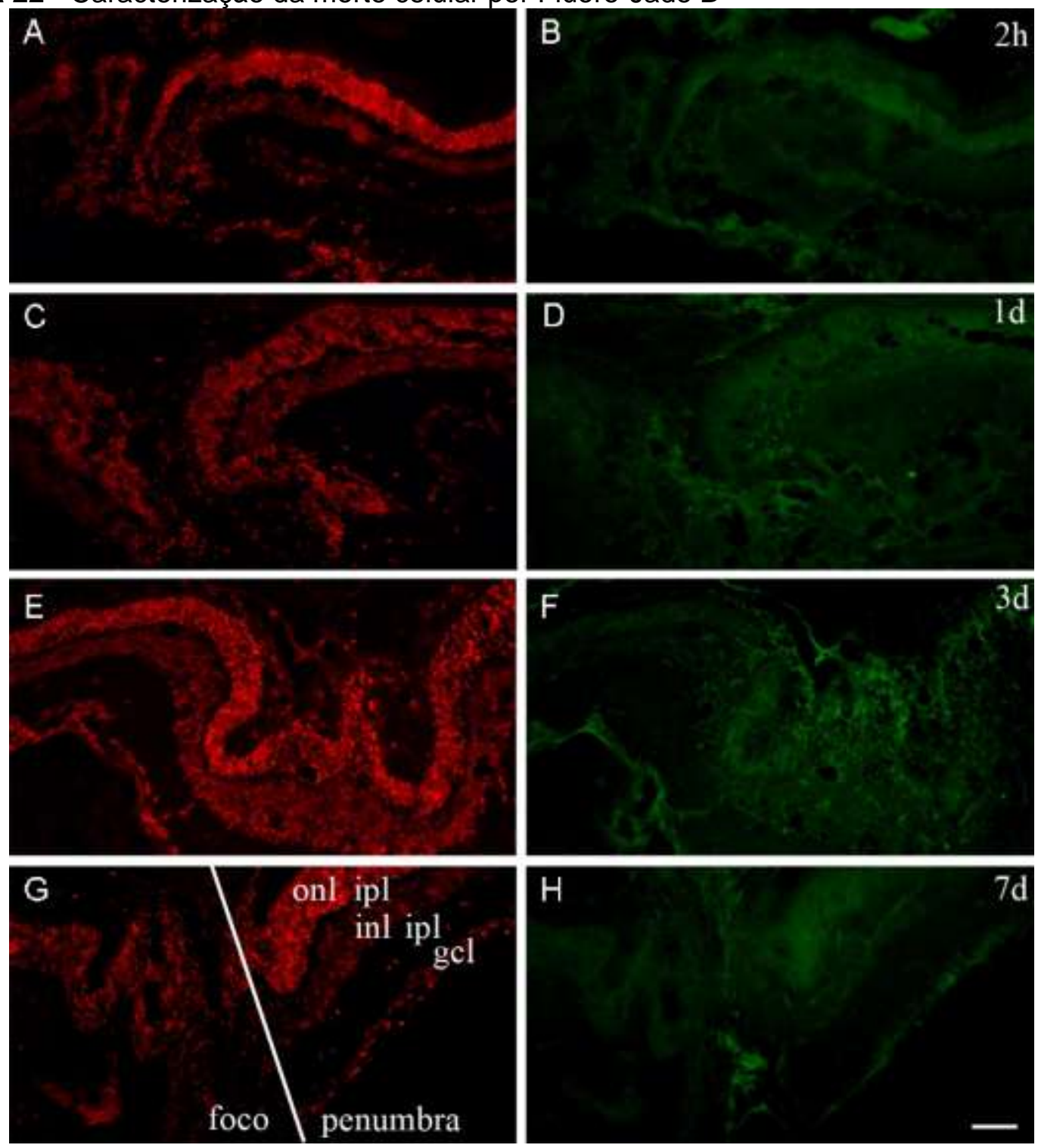

Utilizando o marcador histoquímico Fluoro-Jade B (verde), em retinas contra-coradas por iodeto de propídio (vermelho) observamos alterações no padrão de marcação em (A, B) duas horas; $(C, D)$ um dia; $(E, F)$ três dias; $(G, H)$ sete dias. ONL, camada nuclear externa; OPL, camada plexiforme externa, INL, camada nuclear interna; IPL, camada plexiforme interna; GCL, camada de células ganglionares. Barra de escala: $50 \mu \mathrm{m}$.

FONTE: Higa (2012)

\subsubsection{Dinâmica da morte celular por apoptose no presente modelo de neurodegeneração}

Utilizando a técnica de TUNEL, caracterizamos a morte celular por apoptose em nosso modelo, nos períodos de duas horas, sei horas, um dia e sete dias pós-lesão. 
Nossos resultados indicaram um número particularmente elevado de células exibindo núcleos TUNEL-positivos no período de um dia pós-lesão (Figura 23).

Figura 23 - Caracterização da morte celular por apoptose utilizando a técnica de TUNEL
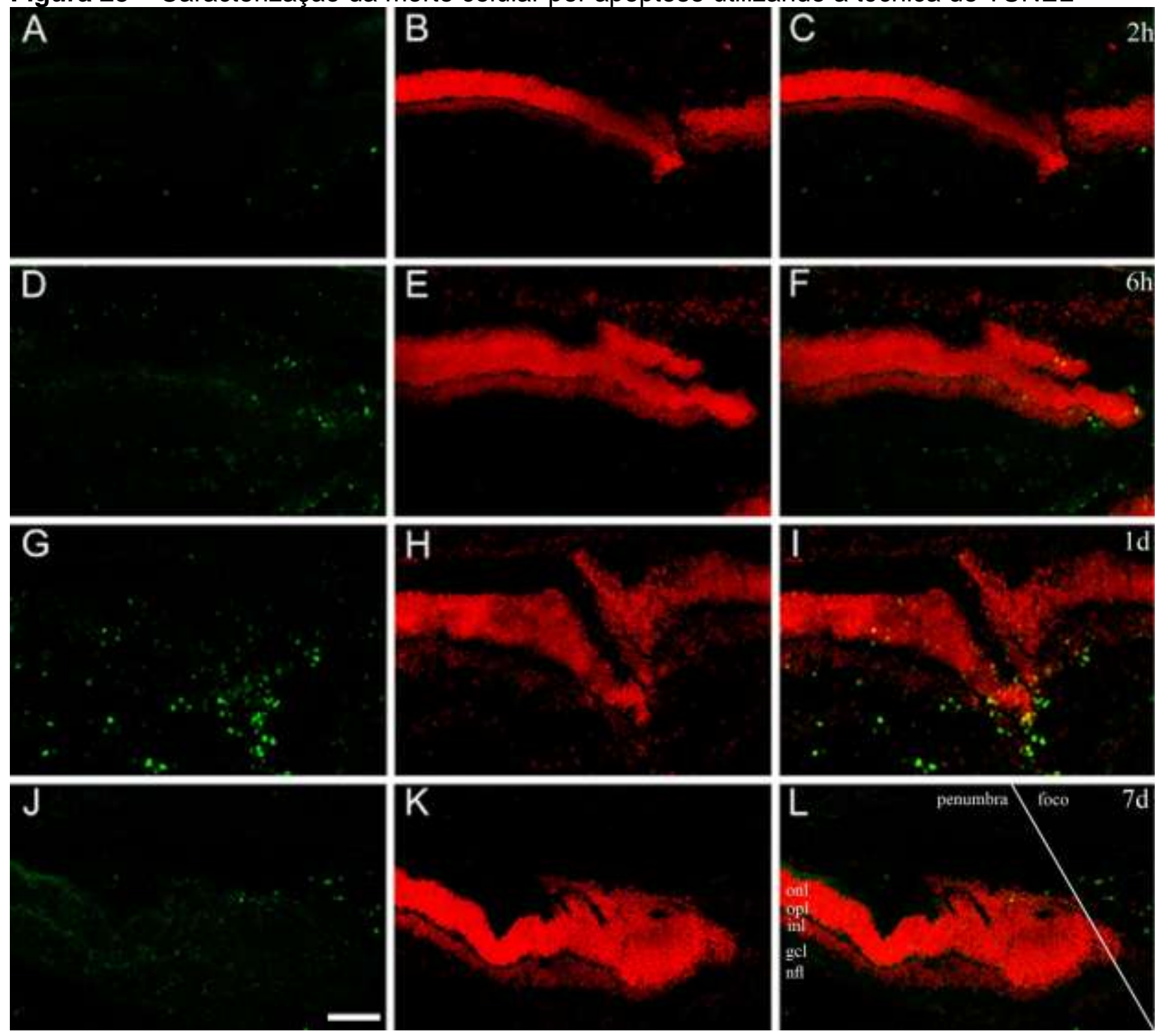

Caracterização da morte celular por apoptose utilizando a técnica de TUNEL (verde), em retinas contra coradas por iodeto de propídio (vermelho). (A-C) 2 horas; (D-F) 6 horas; (G-I) 1 dia; (J-L) 7 dias. ONL, camada nuclear externa; OPL, camada plexiforme externa, INL, camada nuclear interna; IPL, camada plexiforme interna; GCL, camada de células ganglionares. Barra: $60 \mu \mathrm{m}$.

FONTE: Higa (2012) 
4.3.5 Possível correlação da expressão de Cx36 e células em apoptose na degeneração da retina por trauma mecânico

Considerando que a morte celular por apoptose é particularmente evidente em nosso modelo após um dia de lesão, realizamos experimentos de tripla marcação para avaliar a possível relação entre a expressão de Cx36 e células TUNEL positivas. Nossos resultados preliminares indicaram que expressão de Cx36 frequentemente é observada nas proximidades de células exibindo núcleos TUNEL-positivos após um dia de lesão (Figura 24).

Figura 24 - Analises de tripla marcação indicando proximidade de marcação da Cx6 e núcleos TUNEL positivos
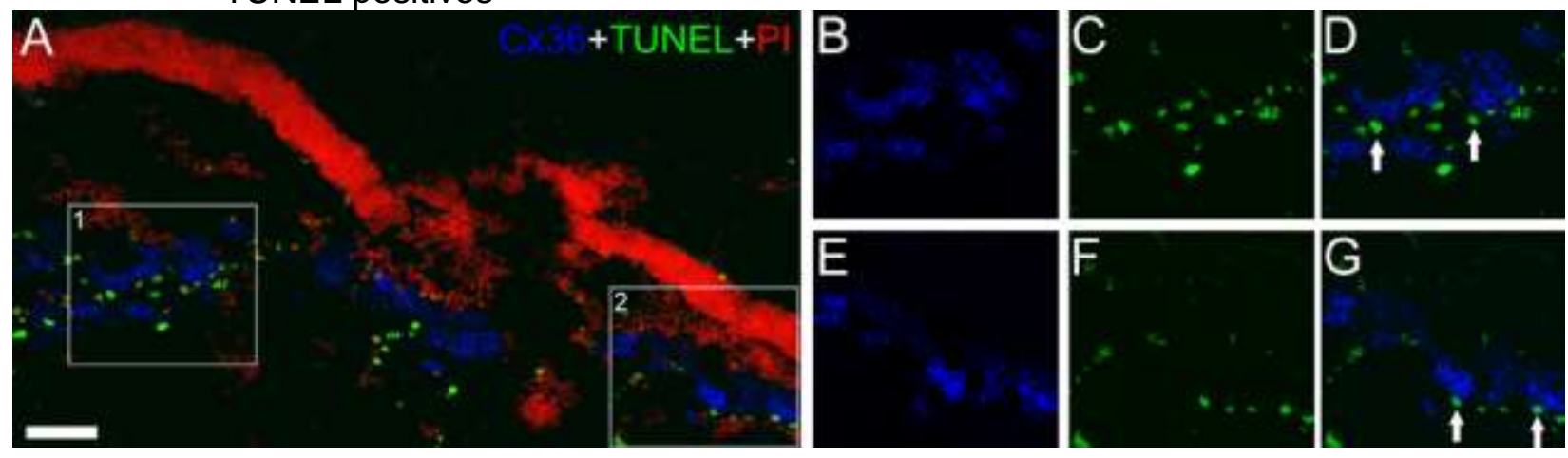

Análise por microscopia confocal indicando possível relação da expressão de Cx36 (azul) e de células em morte celular por apoptose utilizando a técnica de TUNEL (verde), em retinas contra coradas por iodeto de propídio (vermelho). As setas nas imagens ampliadas (B-D, E-G) de áreas selecionadas (1,2), respectivamente, indicam expressão de Cx36 em proximidade com células exibindo núcleos apoptóticos. Barra: $60 \mu \mathrm{m}$.

FONTE: Higa (2012) 
5 DISCUSSÃO 


\subsection{PREDOMÍNIO DA MORTE CELULAR SECUNDÁRIA EM RETINAS LESADAS}

O dano neuronal no sistema nervoso central é caracterizado pela perda celular primária, induzida diretamente pela lesão, e posteriormente por uma morte celular secundária dos neurônios (Kermer et al., 1999). Esse fenômeno pode prolongar e aumentar o trauma gerado pela lesão inicial (Striedinger et al., 2005). Diversos mecanismos são propostos para evidenciar a morte celular secundária, dentre elas a alteração da concentração de íons no meio extracelular, depleção energética, aumento dos níveis de glutamato, como também de neurotransmissores e podem ocasionar alterações na homeostase do cálcio no interior das células.

Através das técnicas de imuno-histoquímica, Fluoro-Jade B e TUNEL, o modelo de lesão mecânica foi caracterizado como um método efetivo para estudos de padrões neurodegenerativos. Os dados demonstraram um aumento gradativo da marcação de Fluoro-Jade B e TUNEL, apresentando um pico nas retinas de um dia pós-lesão, e apresentando uma menor marcação após este período. Estes resultados corroboram com os estudos de lesão a laser e isquêmica, onde foi evidenciado o mesmo padrão gradativo de marcação por TUNEL nos diferentes períodos pós-lesão analisados, apresentado uma diminuição de células em processos neurodegenerativos após períodos pós-lesão semelhantes (Kuroiwa et al., 1998; Striedinger et al., 2005).

O padrão de marcação por Fluro-Jade B possui afinidade por células em degeneração e pode sinalizar de forma similar eventos necróticos e apoptóticos, caracterizando, portanto, a morte celular de forma inespecífica. Nossos resultados sugerem que o modelo de lesão utilizado favorece a morte celular secundária, já que nos períodos mais próximos de indução da lesão (duas e seis horas) encontramos menor concentração de núcleos apoptóticos, os quais foram observados amplamente em períodos mais tardios. Essas observações vão de encontro com modelos de lesão mecânica efetuados em encéfalos de ratos, onde a morte celular secundaria de neurônios nas áreas lesadas se mostrou mais evidente após 24 horas (Alzheimer, 2002). 


\subsection{A C×36 ESTÁ PRESENTE EM CÉLULAS APOPTÓTICAS}

Nossos estudos indicaram que os níveis proteicos totais da Cx36, assim como a expressão gênica referente a essa proteína, não foram alterados pela indução dos processos neurodegenerativos evocados pela lesão. Apesar dos níveis proteicos totais da Cx36 não estarem alterados nas retinas expostas a lesão, sua distribuição é alterada ocorrendo um acumulo nas proximidades do foco da lesão após um dia de sua indução. Os resultados apresentados nesse trabalho indicam que a quantificação das proteínas totais da retina possa ser ineficaz na detecção de sinais sutis de alterações pontuais, gerado pelo modelo adotado nesse estudo. O método de PCR Real-Time apresenta a sensibilidade necessária para detecção de alterações menores nos níveis de RNAm da proteína em questão, porém resultados apontados por Striedinger et al. (2005) , em estudos de lesão retiniana por laser e Kihara et al. (2006) em estudos de adaptação ao escuro, indicam que a expressão da Cx36 pode ser modulada por fatores póstranscricionais, já que mesmo ocorrendo aumento nos níveis proteicos, os níveis do RNAm da Cx36 não são alterados nessas condições.

Os dados apresentados pelo experimento de imuno-histoquímica com tripla marcação para PI, TUNEL e CX36 nas retinas de um dia pós-lesão, demonstraram uma grande população de células TUNEL positivas na camada INL e GCL da retina, locais onde se concentram grandes quantidades de células amácrinas com processos que arborizam na IPL, camada plexiforme com alta concentração de Cx36. Esse dado sugere que as células em processos apoptóticos apresentam-se acopladas. De acordo com estudos realizados, as camadas INL e ONL concentram pericários de neurônios que expressam Cx36 como as células amácrinas, células bipolares tipo "on" e cones (Feigenspan et al., 2001, 2004).

$\mathrm{O}$ acoplamento neuronal mediado pela $\mathrm{C} \times 36$ pode favorecer a passagem de metabólitos específicos, como ATP e glicose, de células não prejudicadas para células danificadas que apresentam uma privação energética, podendo assim as JCs neuronais desempenhar um papel neuroprotetor (De Maio, 2002). Em estudos de lesão na retina através da lesão por indução a laser, a utilização de bloqueadores (quinina e CBX) culminou no aumento de marcação de células TUNEL positivas (Striedinger et al., 2005). Porém, alguns estudos sugerem que as JCs podem auxiliar na dispersão de 
sinais necróticos e apoptóticos de células estressadas ou em processo de degeneração para células vizinhas saudáveis, contribuindo para o aumento no tecido (Frantseva et al., 2002a, b; Rawanduzy et al., 1997).

Uma possível explicação para essa discrepância é que o resultado parece depender do tipo de $\mathrm{Cx}$ envolvida na $\mathrm{JC}$, do modelo animal em estudo e do agente causador da lesão. Tanto a localização da JC como o subtipo molecular da Cx envolvida podem ser determinantes no tipo de sinalização podendo atuar a favor ou contra a propagação da morte celular secundária (Perez Velazquez et al., 2003).

\subsection{AUMENTO DA CX43 EM RESPOSTA À LESÃO}

Assim como a Cx36, as analises dos níveis proteicos totais através de experimentos com Western Blot indicaram ausência de alterações significativas nos

diferentes tempos pós-lesão analisados. Como já evidenciado, aparentemente o modelo experimental adotado nesse estudo não gera alterações significativas na quantidade total de proteínas da retina. Diferentemente dos resultados de Western Blot, as análises imuno-histoquímicas apontaram aumento da Cx43 na lesão (região de foco e penumbra) em todos os períodos analisados. Os resultados de PCR em tempo real indicaram, da mesma forma, um aumento expressivo do RNA mensageiro da Cx43 nos períodos de três e sete dias pós-lesão. Sendo assim diferentemente da Cx36, a modulação dos níveis proteicos da $\mathrm{C} \times 43$ próximos à lesão parece estar relacionada com o aumento da expressão gênica dessa proteína.

O aumento da Cx43 na gliose reativa é evidenciado em outros modelos de indução da neurodegeneração (Cotrina et al., 1998; Fonseca et al., 2002; Kimelberg et al., 1990). A lesão tecidual provoca prejuízos funcionais e estruturais, porém, estudos mostram que, com a deleção da maior parte da Cx43 por utilização de técnicas de knock down seletivo para esse gene pode haver uma diminuição do trauma do tecido (Frantseva et al., 2002a, b).

Por meio de testes de tripla marcação com PI, GFAP e Cx43, foi observado um evidente aumento da $\mathrm{C} \times 43$ proveniente do epitélio pigmentado da retina. Sabe-se que os hemicanais de Cx43 presentes na membrana celular das células desse tecido são responsáveis pela liberação de ATP durante o desenvolvimento da retina, atuando 
como neuromodulador que induz a proliferação de células da retina através da ativação da liberação de cálcio intercelular (Pearson et al., 2004). Deste modo, apesar do epitélio não apresentar comunicação direta com a retina através das JCs, esse tecido pode apresentar certa influência sobre processos de cicatrização e regulação do ciclo celular na retina em processos neurodegenerativos.

\subsection{AUMENTO DA EXPRESSÃO DE CICLINAS}

De forma semelhante das conexinas, nossos resultados de Western Blot da ciclina D1 apontaram a ausência de alteração significativa dos níveis proteicos totais desta proteína em diferentes tempos de exposição à lesão. Análises da expressão genica de ambas ciclinas estudadas (ciclinas D1 e B1) demonstraram aumentar os níveis de RNAm de forma significativa em um, três e sete dias pós-lesão, sendo que após três dias de exposição a lesão, as alterações nos transcritos de ambas ciclinas apresentaram-se maiores. Desse modo, como já destacado anteriormente, é possível que a técnica de Western Blot seja uma técnica ineficaz para detecção das alterações locais dos níveis proteicos ocasionados pelo modelo de lesão aguda.

Nossos resultados de imuno-histoquímica, assim como nossos resultados de PCR em tempo real, corroboram com estudos de processos isquêmicos na retina de roedores (Kuroiwa et al., 1998), onde se demonstrou indução do aumento da expressão da ciclina D1 e B1 em períodos semelhantes de exposição à lesão. Da mesma forma, que nos estudos de Kuoiwa et al. (1998) nossos resultados de imunoistoquímica apontaram um aumento dos níveis de marcação para ciclina D1 em células localizadas na camada nuclear interna (INL) e na camada de células ganglionares (GCL). De acordo com estudos de processos neurodegenerativos da retina, a expressão proteica da ciclina D1 na INL corresponde a células de Müller (Kohno et al., 2006, 1998; Tackenberg et al., 2009). Kuroiwa et al. (1998) utilizando modelo de isquemia em retina de ratos, registraram células apoptóticas apresentando expressão de ciclina D1 na retina nas diferentes camadas nucleares da retina. Em nossos estudos observamos células da GCL apresentando marcação de ciclina D1 nas áreas adjacentes da lesão. Diferentemente do padrão apresentado na INL, na qual a ciclina D1 aparentemente esta alocada no núcleo das células afetadas secundariamente pela lesão, a ciclina D1 
apresenta-se alocada em processos. Analises de tripla marcação com ciclina D1, GFAP e DAPI, indicaram que a ciclina D1 não seja expressa majoritariamente pelas células da macroglia, como os astrócitos. Deste modo é possível que a ciclina D1 seja expressa por células ganglionares da retina. Desta forma as células ganglionares poderiam representar células neuronais reentrando no ciclo celular.

Assim como a ciclina D1, os resultados de imuno-histoquímica indicaram a presença da marcação da ciclina B1 em células afetadas secundariamente a lesão (um dia pós-lesão). A ciclina B1 apresentou-se concentrada no foco e imediações a lesão com um padrão de marcação puntiforme e não nuclear.

$A$ indução das ciclinas da família $D$ e de outros genes relacionados com a progressão do ciclo celular em neurônios pós-mitóticos são consideradas indicadores de morte celular programada. A expressão de diferentes moléculas do ciclo celular tem sido registrada como precedente a morte excitotóxica em diferentes modelos experimentais (Nguyen et al., 2002) assim como a diminuição da expressão das moléculas inibidoras de CDK (CKI) (Krantic et al., 2005).

A indução da lesão mecânica na retina de ratos se trata de um modelo de indução aguda na neurodegeneração. De modo geral, a indução da reentrada do ciclo celular gerada pela ativação do complexo ciclina D-CDK4/6, e a consequente fosforilação da Rb e liberação da E2F, em danos agudos no SNC, é bloqueada entre as fases $\mathrm{G} 1$ e $\mathrm{S}$ do ciclo celular, ocorrendo à morte celular após esse evento (Wang et al., 2009).

O aumento da expressão da ciclina B1 pode estar relacionado com a reentrada do ciclo celular das células de Müller nas retinas lesadas. Estas células podem eventualmente completar o ciclo celular, ocorrendo sua proliferação (Kuroiwa et al., 1998; Tackenberg et al., 2009). Em estudos de lesão isquêmica na retina de roedores foi observada que a expressão proteica da ciclina B1 ocorre apenas em células de Müller, não estando presente em células neuronais (Kuroiwa et al., 1998).

Porém os resultados de imuno-histoquimica apontaram um padrão de expressão pontual e não nuclear da ciclina B1 em resposta a lesão, demonstrando que nas células que expressão essa proteína não ocorre a translocação da mesma para núcleo, não acionando a progressão efetiva da fase G2 para a fase M do ciclo celular. Quando a 
ciclina B1 é altamente expressa e ativa a CDK1 no citoplasma da célula, o complexo ciclina B-CDK1 age fosforilando proteínas do citoesqueleto celular. Esse processo pode induzir a apoptose (Wang et al., 2009)

\subsection{INDUÇÕES DA REENTRADA NO CICLO CELULAR NAS CÉLULAS DA RETINA PELA LESÃO NÃO GERA DIMINUIÇÃO NA EXPRESSÃO DE CONEXINAS}

De forma resumida, a lesão pontual na retina gera aumento das Cxs gliais e mantém estável os níveis totais das Cxs neuronais, assim como o aumento de proteínas reguladoras de diferentes fases do ciclo celular. Esta correlação levanta a possibilidade de que as células que reentram no ciclo celular expressam Cxs, proteínas responsáveis pelo acoplamento via JC.

Diferentes estudos apontam que tipos distintos de Cxs, presente em células de tecidos específicos, apresentam modos de regulação diferenciados de acordo com o estágio do ciclo celular no qual a célula se encontra (Vinken et al., 2011). Deste modo, a presença da ciclina D1 em células próximas ao foco da lesão, demonstra que essas são induzidas a reentrar no ciclo celular, sem, porém diminuir os níveis das Cxs disponíveis para eventual formação das JC, tanto em células gliais como em neurônios.

A Cx43, especificamente, pode ser regulada pela ativação de vias especificas da MAPK. Estas vias, além da habitual função de regular a proliferação celular, são conhecidas por estarem ativas em doenças neurodegenerativas, como a doença de Alzheimer e Parkinson, gerando aumento da expressão das Cxs gliais (Kim et al.,2010).

Apesar de que até o momento não ser conhecida a influência das vias clássicas de regulação do ciclo celular sob a modulação da expressão das Cxs neuronais, estudos recentes indicam que a estimulação contínua de receptores metabotrópicos glutamatérgicos (mGluRs) do grupo II, desencadeada pela a liberação exacerbada de glutamato durante a indução da morte neuronal, aumenta a expressão da Cx36 e favorece o aumento da comunicação via JC (Wang et al., 2012).

Desta forma a indução da lesão na retina deflagraria a liberação de fatores que regulariam de forma secundaria a expressão das proteínas reguladoras do ciclo celular e das Cxs nas células adjacentes a lesão. Além disso, a comunicação entre as células afetadas pela via direta das JC poderia influenciar a reentrada do ciclo celular de 
células pós-mitóticas da retina. De fato, existem trabalhos que corroboram com essa hipótese, tais como os estudos onde foram utilizados bloqueadores de JCs. A restrição da via de comunicação direta entre as células poderia influenciar a regulação da expressão da ciclina D1 e D3 em astrócitos (Tabernero et al., 2006) e até mesmo influenciar o desenvolvimento de regiões específicas do sistema nervoso, a histogênese, como a retina (Kihara et al., 2010). Moléculas permeáveis as JC, como o AMPc (Zhang et al., 2003a, b), o cálcio e o IP 3 (Feller, 2002; Wong, 1999), são conhecidas por apresentar papéis modulatórios nos eventos relacionados com o ciclo celular durante o desenvolvimento ou regeneração.

De forma geral, a lesão pode ocasionar a liberação de fatores que desencadeiam a reentrada do ciclo celular e a modulação das concentrações de Cxs (neuronais e gliais). Portanto as células acometidas a reentrarem no ciclo celular podem se comunicar, através das JC, com células não afetadas por esses fatores. De forma secundaria, as células afetadas indiretamente pela lesão, poderiam espalhar moléculas reguladoras do ciclo celular, sincronizando a reentrada do ciclo celular entre as células acopladas. 
- Os resultados apontaram que o modelo de lesão mecânica utilizado evidencia a morte neuronal secundária;

- os padrões de expressão gênica e níveis proteicos da Cx43 apresentaram modulação pontual após os diferentes períodos pós-lesão analisados, sendo que este resultado pode estar relacionado com o aumento de sua expressão no epitélio pigmentado da retina e à indução da gliose reativa;

- a Cx36 apresentou aparente alteração em sua distribuição na retina após a exposição aos diferentes períodos pós-lesão;

- aparentemente as células apoptóticas encontram-se acopladas por JCs formadas por $\mathrm{C} \times 36$. Este acoplamento poderia influenciar no espalhamento ou diminuição da morte neuronal;

- a expressão gênica das ciclinas D1 e B1, assim como a presença dessas proteínas nas áreas adjacentes a lesão se encontram aumentadas nos diferentes períodos pós-lesão analisados;

- a indução do trauma local na retina favorece o aumento das proteínas reguladoras do ciclo celular, assim como a redistribuição das Cxs neuronais e gliais, indicando a possível presença de acoplamento das células que reentram no ciclo celular. 


\section{REFERÊNCIAS*}

Alzheimer $\mathrm{C}$. $\mathrm{Na}$ + channels and $\mathrm{Ca} 2+$ channels of the cell membrane as targets of neuroprotective substances. Advances in Experimental Medicine and Biology. 2002;513:161-81.

Bao X, Chen Y, Reuss L, Altenberg GA. Functional expression in Xenopus oocytes of gap-junctional hemichannels formed by a cysteine-less connexin 43. The Journal of biological chemistry. 2004;279:9689-92.

Becker D, Bonness V, Mobbs P. Cell coupling in the retina: patterns and purpose. Cell Biol Int. 1998;22:781-92.

Becker DL, Bonness V, Catsicas M, Mobbs P. Changing patterns of ganglion cell coupling and connexin expression during chick retinal development. Journal of neurobiology. 2002;52:280-93.

Bennett MV, Barrio LC, Bargiello TA, Spray DC, Hertzberg E, Saez JC. Gap junctions: new tools, new answers, new questions. Neuron. 1991;6:305-20.

Bittman K, Owens DF, Kriegstein AR, LoTurco JJ. Cell coupling and uncoupling in the ventricular zone of developing neocortex. The Journal of neuroscience : the official journal of the Society for Neuroscience. 1997;17:7037-44.

Bittman KS, LoTurco JJ. Differential regulation of connexin 26 and 43 in murine neocortical precursors. Cereb Cortex. 1999;9:188-95.

Bloomfield SA, Volgyi B. The diverse functional roles and regulation of neuronal gap junctions in the retina. Nature reviews. Neuroscience. 2009;10:495-506.

Carystinos GD, Kandouz M, Alaoui-Jamali MA, Batist G. Unexpected induction of the human connexin 43 promoter by the ras signaling pathway is mediated by a novel putative promoter sequence. Molecular pharmacology. 2003;63:821-31.

Cotrina ML, Kang J, Lin JH, Bueno E, Hansen TW, He L, Liu Y, Nedergaard M. Astrocytic gap junctions remain open during ischemic conditions. The Journal of neuroscience : the official journal of the Society for Neuroscience. 1998;18:2520-37.

Cusato K, Bosco A, Rozental R, Guimaraes CA, Reese BE, Linden R, Spray DC. Gap junctions mediate bystander cell death in developing retina. The Journal of neuroscience : the official journal of the Society for Neuroscience. 2003;23:6413-22.

Dang L, Pulukuri S, Mears AJ, Swaroop A, Reese BE, Sitaramayya A. Connexin 36 in photoreceptor cells: studies on transgenic rod-less and cone-less mouse retinas. Molecular vision. 2004;10:323-7.

${ }^{*}$ De acordo com:

International Committee of Medical Journal Editors. Uniform requirements fos manuscripts submitted to Biomedcal Journal: sample references. Available from: http://www.icmje.org [2007 May 22]. 
Deans MR, Volgyi B, Goodenough DA, Bloomfield SA, Paul DL. Connexin36 is essential for transmission of rod-mediated visual signals in the mammalian retina. Neuron. 2002;36:703-12.

Dreher Z, Distler C, Dreher B. Vitread proliferation of filamentous processes in avian Muller cells and its putative functional correlates. The Journal of comparative neurology. 1994;350:96-108.

Feigenspan A, Janssen-Bienhold U, Hormuzdi S, Monyer H, Degen J, Sohl G, Willecke $\mathrm{K}$, Ammermuller J, Weiler R. Expression of connexin36 in cone pedicles and OFF-cone bipolar cells of the mouse retina. The Journal of neuroscience : the official journal of the Society for Neuroscience. 2004;24:3325-34.

Feigenspan A, Teubner B, Willecke K, Weiler R. Expression of neuronal connexin36 in All amacrine cells of the mammalian retina. The Journal of neuroscience : the official journal of the Society for Neuroscience. 2001;21:230-9.

Feller MB. The role of $\mathrm{nAChR}$-mediated spontaneous retinal activity in visual system development. Journal of neurobiology. 2002;53:556-67.

Fonseca CG, Green CR, Nicholson LF. Upregulation in astrocytic connexin 43 gap junction levels may exacerbate generalized seizures in mesial temporal lobe epilepsy. Brain research. 2002;929:105-16.

Frantseva MV, Kokarovtseva L, Naus CG, Carlen PL, MacFabe D, Perez Velazquez JL. Specific gap junctions enhance the neuronal vulnerability to brain traumatic injury. The Journal of neuroscience: the official journal of the Society for Neuroscience. 2002a;22:644-53.

Frantseva MV, Kokarovtseva L, Perez Velazquez JL. Ischemia-induced brain damage depends on specific gap-junctional coupling. Journal of cerebral blood flow and metabolism : official journal of the International Society of Cerebral Blood Flow and Metabolism. 2002b;22:453-62.

Gorbe A, Becker DL, Dux L, Krenacs L, Krenacs T. In differentiating prefusion myoblasts connexin43 gap junction coupling is upregulated before myoblast alignment then reduced in post-mitotic cells. Histochemistry and cell biology. 2006;125:705-16.

Gorbe A, Becker DL, Dux L, Stelkovics E, Krenacs L, Bagdi E, Krenacs T. Transient upregulation of connexin43 gap junctions and synchronized cell cycle control precede myoblast fusion in regenerating skeletal muscle in vivo. Histochemistry and cell biology. 2005;123:573-83.

Guegan C, Levy V, David JP, Ajchenbaum-Cymbalista F, Sola B. C-Jun and cyclin D1 proteins as mediators of neuronal death after a focal ischaemic insult. Neuroreport. 1997;8:1003-7. 
Guldenagel M, Sohl G, Plum A, Traub O, Teubner B, Weiler R, Willecke K. Expression patterns of connexin genes in mouse retina. The Journal of comparative neurology. 2000;425:193-201.

Hidaka S, Kato T, Miyachi E. Expression of gap junction connexin36 in adult rat retinal ganglion cells. J Integr Neurosci. 2002;1:3-22.

Hombach S, Janssen-Bienhold U, Sohl G, Schubert T, Bussow H, Ott T, Weiler R, Willecke K. Functional expression of connexin57 in horizontal cells of the mouse retina. The European journal of neuroscience. 2004;19:2633-40.

Jiang JX, Gu S. Gap junction- and hemichannel-independent actions of connexins. Biochim Biophys Acta. 2005;1711:208-14.

Lwis JBA, Walter P, Johson A, Hopkin K, Bray D, Raff M, Roberts K. Fundamentos da Biologia celular Umalntrodução a Biologia Molecular da Célula. Journal. 2004.

Kandel ER, Schwartz JH, Jessel TM. Princípios de Neurociência. 4" ed Barueri SP: Manole; 2003. $1412 \mathrm{p}$.

Katchanov J, Harms C, Gertz K, Hauck L, Waeber C, Hirt L, Priller J, von Harsdorf R, Bruck W, Hortnagl H, Dirnagl U, Bhide PG, Endres M. Mild cerebral ischemia induces loss of cyclin-dependent kinase inhibitors and activation of cell cycle machinery before delayed neuronal cell death. The Journal of neuroscience : the official journal of the Society for Neuroscience. 2001;21:5045-53.

Kermer P, Klocker N, Bahr M. Neuronal death after brain injury. Models, mechanisms, and therapeutic strategies in vivo. Cell and tissue research. 1999;298:383-95.

Kihara $\mathrm{AH}$, de Castro LM, Moriscot AS, Hamassaki DE. Prolonged dark adaptation changes connexin expression in the mouse retina. Journal of neuroscience research. 2006a;83:1331-41.

Kihara AH, Mantovani de Castro L, Belmonte MA, Yan CY, Moriscot AS, Hamassaki DE. Expression of connexins 36,43 , and 45 during postnatal development of the mouse retina. Journal of neurobiology. 2006b;66:1397-410.

Kihara AH, Santos TO, Osuna-Melo EJ, Paschon V, Vidal KS, Akamine PS, Castro LM, Resende RR, Hamassaki DE, Britto LR. Connexin-mediated communication controls cell proliferation and is essential in retinal histogenesis. International journal of developmental neuroscience : the official journal of the International Society for Developmental Neuroscience. 2010;28:39-52.

Kihara AH, Santos TO, Paschon V, Matos RJ, Britto LR. Lack of photoreceptor signaling alters the expression of specific synaptic proteins in the retina. Neuroscience. 2008;151:995-1005. 
Kim EK, Choi EJ. Pathological roles of MAPK signaling pathways in human diseases. Biochimica et biophysica acta. 2010;1802:396-405.

Kimelberg HK, Goderie SK, Higman S, Pang S, Waniewski RA. Swelling-induced release of glutamate, aspartate, and taurine from astrocyte cultures. The Journal of neuroscience : the official journal of the Society for Neuroscience. 1990;10:1583-91.

Kohno H, Sakai T, Kitahara K. Induction of nestin, Ki-67, and cyclin D1 expression in Muller cells after laser injury in adult rat retina. Graefe's archive for clinical and experimental ophthalmology $=$ Albrecht von Graefes Archiv fur klinische und experimentelle Ophthalmologie. 2006;244:90-5.

Kojima T, Yamamoto T, Lan M, Murata M, Takano K, Go M, Ichimiya S, Chiba H, Sawada N. Inhibition of MAP kinase activity moderates changes in expression and function of $\mathrm{C} \times 32$ but not claudin-1 during DNA synthesis in primary cultures of rat hepatocytes. Medical Electron Microscopy: Official Journal of the Clinical Electron Microscopy Society of Japan. 2004;37:101-13.

Kranenburg O, van der Eb AJ, Zantema A. Cyclin D1 is an essential mediator of apoptotic neuronal cell death. The EMBO Journal. 1996;15:46-54.

Krantic S, Mechawar N, Reix S, Quirion R. Molecular basis of programmed cell death involved in neurodegeneration. Trends in Neurosciences. 2005;28:670-6.

Krishna M, Narang $\mathrm{H}$. The complexity of mitogen-activated protein kinases (MAPKs) made simple. Cellular and molecular life sciences : CMLS. 2008;65:3525-44.

Kuroiwa S, Katai N, Shibuki H, Kurokawa T, Umihira J, Nikaido T, Kametani K, Yoshimura N. Expression of cell cycle-related genes in dying cells in retinal ischemic injury. Investigative ophthalmology \& visual science. 1998;39:610-7.

Li J, Meyer AN, Donoghue DJ. Nuclear localization of cyclin B1 mediates its biological activity and is regulated by phosphorylation. Proceedings of the National Academy of Sciences of the United States of America. 1997;94:502-7.

Linden R. The anti-death league: associative control of apoptosis in developing retinal tissue. Brain Res Brain Res Rev. 2000;32:146-58.

Lo CW. The role of gap junction membrane channels in development. Journal of Bioenergetics and Biomembranes. 1996;28:379-85.

Maeda S, Tsukihara T. Structure of the gap junction channel and its implications for its biological functions. Cellular and molecular life sciences: CMLS. 2011;68:1115-29.

Malumbres M, Barbacid M. Mammalian cyclin-dependent kinases. Trends in biochemical sciences. 2005;30:630-41. 
Mills SL, O'Brien JJ, Li W, O'Brien J, Massey SC. Rod pathways in the mammalian retina use connexin 36. The Journal of comparative neurology. 2001;436:336-50.

Nguyen MD, Mushynski WE, Julien JP. Cycling at the interface between neurodevelopment and neurodegeneration. Cell death and differentiation. 2002;9:1294306.

Oyamada M, Oyamada Y, Takamatsu T. Regulation of connexin expression. Biochimica et biophysica acta. 2005;1719:6-23.

Pardee AB. G1 events and regulation of cell proliferation. Science. 1989;246:603-8.

Pearson RA, Catsicas M, Becker DL, Bayley P, Luneborg NL, Mobbs P. Ca(2+) signalling and gap junction coupling within and between pigment epithelium and neural retina in the developing chick. The European journal of neuroscience. 2004;19:2435-45.

Perez Velazquez JL, Frantseva MV, Naus CC. Gap junctions and neuronal injury: protectants or executioners? The Neuroscientist : a review journal bringing neurobiology, neurology and psychiatry. 2003;9:5-9.

Pines J. Cyclins and their associated cyclin-dependent kinases in the human cell cycle. Biochemical Society transactions. 1993;21:921-5.

Pines J. Mitosis: a matter of getting rid of the right protein at the right time. Trends in cell biology. 2006;16:55-63.

Rawanduzy A, Hansen A, Hansen TW, Nedergaard M. Effective reduction of infarct volume by gap junction blockade in a rodent model of stroke. Journal of neurosurgery. 1997;87:916-20.

Roerig B, Feller MB. Neurotransmitters and gap junctions in developing neural circuits. Brain research. Brain research reviews. 2000;32:86-114.

Sohl G, Guldenagel M, Traub O, Willecke K. Connexin expression in the retina. Brain research. Brain research reviews. 2000;32:138-45.

Spray DC, Ye ZC, Ransom BR. Functional connexin "hemichannels": a critical appraisal. Glia. 2006;54:758-73.

Stellwagen D, Shatz CJ, Feller MB. Dynamics of retinal waves are controlled by cyclic AMP. Neuron. 1999;24:673-85.

Stone J, Dreher Z. Relationship between astrocytes, ganglion cells and vasculature of the retina. The Journal of comparative neurology. 1987;255:35-49.

Stork PJ, Schmitt JM. Crosstalk between CAMP and MAP kinase signaling in the regulation of cell proliferation. Trends in cell biology. 2002;12:258-66. 
Striedinger K, Petrasch-Parwez E, Zoidl G, Napirei M, Meier C, Eysel UT, Dermietzel R. Loss of connexin36 increases retinal cell vulnerability to secondary cell loss. The European journal of neuroscience. 2005;22:605-16.

Tabernero A, Sanchez-Alvarez R, Medina JM. Increased levels of cyclins D1 and D3 after inhibition of gap junctional communication in astrocytes. Journal of neurochemistry. 2006;96:973-82.

Tackenberg MA, Tucker BA, Swift JS, Jiang C, Redenti S, Greenberg KP, Flannery JG, Reichenbach A, Young MJ. Muller cell activation, proliferation and migration following laser injury. Molecular vision. 2009;15:1886-96.

Thoreson WB, Witkovsky P. Glutamate receptors and circuits in the vertebrate retina. Prog Retin Eye Res. 1999;18:765-810.

Trovato-Salinaro A, Belluardo N, Frinchi M, von Maltzahn J, Willecke K, Condorelli DF, Mudo G. Regulation of connexin gene expression during skeletal muscle regeneration in the adult rat. American journal of physiology. Cell physiology. 2009;296:C593-606.

Tsutsumi M, Inoue K, Denda S, Ikeyama K, Goto M, Denda M. Mechanical-stimulationevoked calcium waves in proliferating and differentiated human keratinocytes. Cell and tissue research. 2009;338:99-106.

Unwin PN, Zampighi G. Structure of the junction between communicating cells. Nature. 1980;283:545-9.

Uyama N, Shimahara Y, Okuyama H, Kawada N, Kamo S, Ikeda K, Yamaoka Y. Carbenoxolone inhibits DNA synthesis and collagen gene expression in rat hepatic stellate cells in culture. Journal of hepatology. 2003;39:749-55.

Vinken M, Decrock E, De Vuyst E, Ponsaerts R, D'Hondt C, Bultynck G, Ceelen L, Vanhaecke T, Leybaert L, Rogiers V. Connexins: sensors and regulators of cell cycling. Biochimica et biophysica acta. 2011;1815:13-25.

Wang W, Bu B, Xie M, Zhang M, Yu Z, Tao D. Neural cell cycle dysregulation and central nervous system diseases. Progress in neurobiology. 2009;89:1-17.

Wang Y, Song JH, Denisova JV, Park WM, Fontes JD, Belousov AB. Neuronal gap junction coupling is regulated by glutamate and plays critical role in cell death during neuronal injury. The Journal of neuroscience : the official journal of the Society for Neuroscience. 2012;32:713-25.

Webvision. Simple Anatomy of the Retina [homepage on internet]. Utah: Helga Kolb; 2011. Available from: http://webvision.med.utah.edu/book/part-i-foundations/simpleanatomy-of-the-retina/ [2010 Jun 20].

Wong RO. Retinal waves and visual system development. Annu Rev Neurosci. 1999;22:29-47. 
Yamamoto T, Kojima T, Murata M, Takano K, Go M, Hatakeyama N, Chiba H, Sawada N. p38 MAP-kinase regulates function of gap and tight junctions during regeneration of rat hepatocytes. Journal of hepatology. 2005;42:707-18.

Yang Y, Herrup K. Cell division in the CNS: protective response or lethal event in postmitotic neurons? Biochimica et biophysica acta. 2007;1772:457-66.

Zahs KR, Kofuji P, Meier C, Dermietzel R. Connexin immunoreactivity in glial cells of the rat retina. The Journal of comparative neurology. 2003;455:531-46.

Zhang YW, Kaneda M, Morita I. The gap junction-independent tumor-suppressing effect of connexin 43. The Journal of biological chemistry. 2003a;278:44852-6.

Zhang YW, Nakayama K, Morita I. A novel route for connexin 43 to inhibit cell proliferation: negative regulation of S-phase kinase-associated protein (Skp 2). Cancer research. 2003b;63:1623-30. 